\title{
Dopuszczalność ulepszania natury ludzkiej (enhancement) ${ }^{1}$
}

\author{
Justyna Holocher (Uniwersytet Pedagogiczny w Krakowie) \\ Urszula Kosielińska-Grabowska (Uniwersytet Pedagogiczny w Krakowie)
}

\section{Enhancement i zdrowie a therapy i choroba}

Problematyka ulepszania człowieka związana jest $\mathrm{z}$ nurtem określanym mianem transhumanizmu, zakładającym doskonalenie człowieka i możliwość objęcia kontrolą coraz większych obszarów jego aktywności, tak fizycznych, jak i intelektualnych. Transhumanizm określany jest zazwyczaj jako ruch intelektualno-kulturowy, pozytywnie odnoszący się do możliwości, jak i potrzeby, fundamentalnej zmiany ludzkiej kondycji, poprzez wykorzystanie technologii do optymalizacji możliwości człowieka. W tych ramach zajmuje się badaniem konsekwencji, w tym zagrożeń wynikających z użycia nauki, techniki i innych środków twórczych, mających na celu przezwyciężenie podstawowych ludzkich ograniczeń. Łączy w sobie wizje i ideologie $\mathrm{z}$ konkretnymi projektami naukowymi (Vogelsang, Hoppe 2011, 32). Te ostatnie koncentrują się wokół badań i eksperymentów, których przedmiotem jest analiza wywierania wpływu na naturę ludzką ${ }^{2}$ i osiągnięcie celów takich jak przezwyciężenie ludzkich ograniczeń poprzez zwiększenie siły, wytrzymałości, odporności, sprawności fizycznej oraz możliwości regeneracji, ale także poprawienie możliwości kognitywnych $\mathrm{w}$ postaci usprawnienia myślenia czy polepszenia pamięci. Dokonuje się to przy zastosowaniu farmakologii, technologii, w tym neurotechnologii, nanotechnologii, biotechnologii, krioniki, ulepszonych protez, czy za sprawą wykorzystania technik kognitywistycznych oraz inżynierii genetycznej. Może dotyczyć więc zarówno cech wrodzonych, jak i nabytych.

\footnotetext{
${ }^{1}$ Projekt został sfinansowany ze środków Narodowego Centrum Nauki przyznanych na podstawie decyzji numer DEC-2013/10/E/HS5/00157.

2 Filozoficzna ocena ulepszania natury ludzkiej koncentruje się zwykle na jej antropologicznej koncepcji, która odwołuje się do przekonania, że człowiek posiada specyficzne cechy, które wyróżniają go spośród innych istot żywych. Zwykle sprowadza się je do wolności, moralności i odpowiedzialności. Dlatego natura ludzka, jako dana nam przez Boga albo wytworzona przez procesy ewolucji, jest bezpiecznym punktem wyjścia nie tylko dla tego, co może albo powinno być czynione, ale również dla wskazania na to, czego nie można albo nie powinno się czynić (H. Engelhardt), także w aspekcie prawnym zagadnienia (Zob. Bayertz 2011, 3; Vogelsang, \& Hoppe 2011, 32-34; Hołub 2008).
} 
Problematyczność zagadnienia ulepszania natury ludzkiej wynika z wielu przyczyn. Jedną z nich jest problem definicyjny, związany z wielością wykorzystywanych pojęć. I tak, w ramach analizowanego zagadnienia można spotkać się z takimi określeniami jak: enhancement, ulepszanie, doskonalenie, wzmacnianie, optymalizowanie czy poprawianie natury ludzkiej (zdrowego organizmu, właściwości, którymi zwykle dysponuje). Często są one przeciwstawiane takim pojęciom jak: leczenie czy terapia mające zastosowanie $w$ przypadku zdiagnozowania choroby. Dystynkcje te są kluczowe dla moralnej i prawnej oceny działań związanych z zmianami natury ludzkiej.

Enhancement jest pojęciem podstawowym. W literaturze było i jest ono rozmaicie definiowane oraz wykorzystywane w rozmaitych kontekstach i z różnymi konotacjami (Ferdynus 2013, 11; Fuchs 2002; Presidents Council on Bioethics 2003; Themenheft 2006). Najczęściej jest tłumaczone jako doskonalenie człowieka i jego zdolności (Savulescu 2011, 3). Dlatego też przyjęło je się utożsamiać z interwencją radykalną bądź poprawiającą różnego rodzaju właściwości, które zwykle ludzie posiadają, z tworzeniem nowych, „ulepszonych” parametrów (Parens 1998). Taką nieterapeutyczną optymalizację określa się również jako wzmocnienie czy ulepszanie ${ }^{3}$. Obejmuje ono różnego rodzaju zabiegi, które wykraczają poza utrzymanie organizmu przy życiu dokonywane poprzez poprawę lub przywrócenie pewnych funkcji (Ferdynus 2013,12). Przyjmuje się, że ulepszanie nie zajmuje się stanami chorobowymi, lecz ingeruje w zdrowy organizm; normalnie funkcjonujące ciało lub psychikę, celem poszerzenia czy zoptymalizowania jego możliwości (Savulescu, Sandberg, \& Kahane 2011, 16), a tym samym zwiększenia szansy na dobre życie w określonych okolicznościach (President's Council on Bioethics 2003; Ferdynus 2013, 14). Dlatego termin enhancement traktuje się często jako kontradystynkcję do therapy, która wykorzystuje moc technologiczną do leczenia w celu przywrócenia chorego do normalnego stanu i dobrej kondycji (Ferdynus 2013). W tym zestawieniu kluczowymi są pojęcia zdrowia i choroby. Nie są one wyłącznie teoretyczne. Ich doniosłość przejawia się w sytuacjach konkretnych, dopiero wówczas nabierają bowiem właściwego znaczenia. W stwierdzaniu stanu zdrowia bądź choroby obecne są elementy wartościowania, osadzone w indywidulanych i społecznych oczekiwaniach oraz ocenach. Są one uwarunkowane moralnością, kulturą i obyczajem oraz aktualnym stanem wiedzy medycznej i rozwojem techniki. Współcześnie obserwujemy poszerzenie się stanów określanych jako patologiczne. Włączono do nich różnego rodzaju fobie, obsesje czy zaburzenia

\footnotetext{
${ }^{3}$ Sam termin "wzmocnienie" powstał na gruncie projektów dotyczących genetycznego udoskonalenia organizmu. Z czasem znalazł zastosowanie do wszelkich form ulepszania człowieka. Wzmocnienie może dotyczyć różnych funkcji, zdolności i aspektów życia człowieka i wydaje się, że może być traktowane jako synonim ulepszenia i enhancement (zob. Chyrowicz 2002, 91).
} 
osobowości, utrudniając stworzenie jednej powszechnie obowiązującej i uznanej definicji zdrowia i choroby (Chyrowicz 2002, 91). Tym samym podważono zasadność traktowania tych pojęć jako kryteriów moralnych i prawnych dopuszczalnych ingerencji medycznych (Chyrowicz 2002, 93).

Pomimo wskazanych trudności i wątpliwości podejmuje się jednak próby zdefiniowania zdrowia i choroby4. Najczęściej powoływaną w literaturze jest definicja wypracowana przez WHO. Zgodnie z nią zdrowie to stan cechujący się uzyskaniem dobrego samopoczucia na poziomie fizycznym, psychicznym i społecznym. Choroba ${ }^{5}$ natomiast jest każdym zaburzeniem (zniszczeniem lub dewiacją) prawidłowej struktury lub funkcji jakiejkolwiek części, narządu lub układu ustroju, objawiające się charakterystycznym zespołem objawów, którego etiologia, patologia i rokowanie mogą być znane lub nieznane (Leźnicki \& Lewandowska 2013, 114-127).

Założenia leżące u podstaw sformułowania dystynkcji zdrowie choroba, ulepszanie - leczenie wydają się jasne, natomiast $\mathrm{w}$ wielu przypadkach diagnostycznych i terapeutycznych wyznaczenie granicy pomiędzy leczeniem a ulepszaniem nie jest proste, zarówno w teorii, jak i praktyce ${ }^{6}$. Nie będziemy jednak szczegółowo analizować powyższej problematyki związanej rozróżnieniem stanu choroby i zdrowia. Naszym zdaniem pomoc, bo tak należy rozumieć owe wzmacnianie pacjenta chorego, którą oferuje współczesna medycyna, gdy celem jest powrót lub umożliwienie normalnego funkcjonowania pacjenta, nie budzi specjalnego sprzeciwu. Nie mamy żadnych wątpliwości, że wykorzystanie różnego rodzaju farmaceutyków czy urządzeń stymulujących pracę mózgu po to, aby chory na Alzheimera mógł samodzielnie funkcjonować jest nie tylko uzasadnione, lecz wręcz pożądane. Nie stanowi dla nas też problemu odpowiedź na pytanie o to, czy gdyby istniał środek farmakologiczny pozwalający aby cierpiący na chorobę Parkinsona mogli całkowicie pozbyć się jej objawów, bez narażania się na skutki uboczne bardziej dotkliwe niż sama choroba, to czy należy ich użyć. Podobnie jak użycie leków mających zredukować nadpobudliwość psychoruchową u pacjentów z ADHD. Oczywiście pojawią się w tym miejscu wątpliwości, czy istnieje podstawa do wykluczenia przyszłych, możliwych skutków ubocznych, bowiem nadal nieznane są konsekwencje długotrwałego

4 Zgodnie ze Słownikiem Języka Polskiego PWN zdrowie to: 1. «stan żywego organizmu, w którym wszystkie funkcje przebiegają prawidłowo»; 2. «stan, w jakim znajduje się żywy organizm»; 3. «dobre funkcjonowanie jakiegoś systemu»; www.sjp.pwn.pl; zob. www.nfz.pl.

5 Zgodnie z Słownikiem Języka Polskiego PWN www.sjp.pwn.pl, choroba to: 1. «nieprawidłowe funkcjonowanie organizmu lub jego części»; 2. «negatywne zjawisko lub czyjaś ujemna cecha».

6 Przykładem może tu służyć dyskusja dotycząca szczepień. Według niektórych stanowi ona element leczenia, dla innych przedstawicieli nauki jest przykładem ulepszania. Szczepionka bowiem wyposaża człowieka w dodatkową odporność, której człowiek naturalnie nie posiada (zob. Bostrom \& Roache 2008, 120-121). 
stosowania leków oddziałujących na system nerwowy. Można też stawiać pytania o ich wykorzystanie w innych celach niż lecznicze. Ale czy fakt, że nóż może zarówno służyć do krojenia chleba jak i dokonania zabójstwa oznacza, że mamy zakazać jego używania? Czy fakt, że morfina jest środkiem uśmierzającym ból i przynosi ulgę najbardziej cierpiącym, a jednocześnie jest środkiem silnie uzależniającym i mogącym prowadzić do osłabienia woli, rozleniwienia, zaniku obowiązkowości i uczuciowości, czy spłycenia dążeń życiowych oznacza, że powinno zakazać się jej produkcji i używania? Te pytania są oczywiście niezwykle ważne, jednak odpowiedź na nie wymaga analizy, która znacznie przekraczałaby ramy tego opracowania. W tym miejscu warto jednak zaznaczyć, że problem skutków ubocznych stosowania wszelkiego rodzaju ulepszaczy to zagadnienie z zakresu medycyny. Natomiast kwestia możliwości wykorzystania i dopuszczenia do ich legalnego zastosowania należy już do legislatora, który musi rozstrzygnąć te kwestie. Dotyczy to naturalnie nie tylko farmaceutyków czy technologii związanych z ulepszaniem natury człowieka, ale wszystkich leków.

Pytaniem zasadniczym jest określenie podstaw etycznych dla uznania istnienia obowiązku moralnego i/lub prawnego zażycia czy wykorzystania dostępnych środków i technik ulepszających kondycję człowieka. Rozważmy przypadek szczególnie agresywnych, nadpobudliwych pacjentów czy nadaktywnych skazanych. Jeśli chodzi o tę pierwszą kategorię, to nie jest żadną tajemnicą, że stosowane są wobec nich różne metody mające na celu ich uspokojenie, od stosowania środków bezpośredniego przymusu, po podanie odpowiednich leków. Nie ulega wątpliwości, że leczenie w tym zakresie jest wskazane i powinno być regulowane prawnie. Natomiast kwestia interesującą wydaje się pytanie o to, $\mathrm{w}$ jakim zakresie takiemu leczeniu mogą być poddani skazani. Nie mówimy to o osobach, które dopuściły się przestępstwa, ale w związku ze stwierdzoną choroba przebywają w zakładzie leczniczym, ale o skazanych, którzy wykazują zachowania agresywne, a którym podanie leków uspakajających miałoby na celu „polepszenie”, uspołecznienie ich zachowania. Jak rozwiązać tego rodzaju problem? Kontynuując rozważania w tym kierunku, można dalej stawiać pytania o inne podmioty - jak żołnierze czy lekarze. Osoby, które wykonują szczególnie ważne zadania w społeczeństwie. Czy żołnierz, który wyjeżdża na misję by bronić bezpieczeństwa państwa i jego obywateli powinien w celu zwiększenia swoich zdolności wojennych poddać się zabiegom ulepszającym? Czy chirurg, mający przeprowadzić wielogodzinną i niezwykle skomplikowaną operację, także powinien to uczynić? Można sformułować więc ogólne pytanie, czy zgoda na, a nawet przymus polepszania może być uzależniony od tego, kogo dotyczy i w jakich celach ma być wykorzystany.

Kategorii ulepszania jest wiele. Najczęściej spotykamy się z rozróżnieniem na ulepszanie naturalne i sztuczne oraz wewnętrzne i zewnętrzne. Ulepszaniu natury ludzkiej służą rozmaite środki o charakterze 
naturalnym bądź sztucznym. Wzmacnianie naturalne osiąga się za pomocą ćwiczeń fizycznych i intelektualnych wykonywanych samodzielnie lub przy wykorzystaniu różnego typu narzędzi i maszyn. Polepszanie natury w sposób naturalny, oznacza korzystanie z „naturalnych” źródeł, nie skażonych ludzką interwencją. Są to między innymi naturalne suplementy żywności i sposoby poprawy ludzkich zdolności, takie jak ćwiczenia, dieta czy pielęgnacja (Bostrom \& Sandber 2009). Ten sposób poprawiania natury nigdy nie budził wątpliwości, co więcej, dążenie do udoskonalania - zarówno tego etycznego jak i fizycznego, zawsze był w filozofii postulowany (Judycki 2008). A zatem wykorzystanie środków i metod, które nie miałaby takiego naturalnego źródła, a które w bezpośredni sposób wpływa na ludzkie ciało lub pewien jego aspekt należałby potraktować jako sztuczne (Kamieński 2014, 59). Takie jednak rozróżnienie niewiele wyjaśnia $\mathrm{w}$ dyskusji o ulepszanie człowieka i możliwości jego dopuszczenia. Czy marihuana, będąca naturalną rośliną, jako taka powinna być dopuszczona? Czy transplantacja serca świni powinno być dopuszczalnym ulepszeniem, a użycie sztucznego serca nie? Rozróżnienie na naturalne i sztuczne wzmacnianie jest przedmiotem ożywionej dyskusji w debacie nad ulepszaniem człowieka. Ten aspekt ulepszania, powinien być brany pod uwagę, lecz naszym zdaniem ma on znaczenie marginalne.

By usprawnić procesy kognitywne ludzie używają różnego typu „narzędzi” - by uzyskać informacje albo szybciej i lepiej je zapamiętać. Z jednej strony mogą temu służyć komputery, kalkulatory, kartki czy długopisy, z drugiej zaś można tego dokonać sięgając po medykamenty, od naturalnych i znanych od wieków, jak Ginkgo biloba (Mahadevan \& Park 2008) poprzez najnowsze osiągnięcia farmakologii jak Donepezil (Krupp, Cristodoulou, et al. 2003). Pierwsze $\mathrm{z}$ wymienionych należą do zewnętrznych ulepszeń i są postrzegane jako potencjalnie mniej groźne. Mimo, że mogą wywierać wpływ lub zmieniać sposób myślenia osoby, wydają się mniej ryzykowne niż fizycznie zmiany równowagi chemicznej w mózgu, które wywoływane są przez „wewnętrzne” wzmacniacze. Ulepszenia zewnętrzne zwiększają istniejące lub pozwalają na uzyskanie nowych możliwości człowieka, bez zmiany podstawowych systemów biologicznych, psychologicznych lub poznawczych. Ulepszanie wewnętrzne poszerza istniejące lub włącza nowe możliwości człowieka, zmieniając szczególny aspekt rdzenia systemu biologicznego, psychologicznego lub poznawczego. Nie ulega wątpliwości, że oba typy wzmocnienia pomagają zwiększyć potencjał kognitywny. Jednak celem wewnętrznych ulepszeń jest zmiana funkcjonowania mózgu i jako takie mogą one budzić wątpliwości (BMA 2014).

W literaturze rozróżnia się także ulepszania ze względu na sposoby wzmocnień w postaci zastosowania farmakologii, technologii cyborgicznych i genetyki (Kamieński 2014, 88n.). Przy pomocy pierwszych farmakologicznych - można zarządzać następującymi aspektami aktywności ludzkiej: a) czujnością, snem, zmęczeniem (przy użyciu stymulantów takich 
jak np. deksedryna, modafinil oraz antydepresantów i leków nasennych nowej generacji, go pills i no go pills), b) stresem, pamięcią, emocjami, traumą (polegające na zapobieganiu załamaniom nerwowym - osiągnięciu poczucia bezwydarzeniowości czy hamowaniu farmakologiczne procesów konsolidacji pamięci za pomocą propranololu), c) zaufaniem i spójnością grupową (poprzez zaaplikowanie oksytocyny - hormonu ułatwiającego powstawanie więzi, zwiększającego poziom zaufania, wywierającego wpływ na percepcję społeczną) oraz d) rannymi (poprzez ograniczenie śmiertelności wśród żołnierzy, w wyniku doznanych urazów za sprawą siarczanu etynyloestradiolu, poprzez zastosowanie sztucznej hibernacji czy wydłużenie przydatności krwi).

Drugi rodzaj ulepszeń to zastosowanie technologii cyborgicznej, polegającej na ścisłym funkcjonalnym połączeniu ciała z techniką(Kamieński 2014, 57), co służyć może zarządzaniu: a) personelem (podczas rekrutacji/wyborze kandydatów użyteczne byłyby technologie obrazowania mózgu, a podczas czynnej służby - chipowanie ludzi w celu lokalizacji; a z kolei $\mathrm{w}$ sytuacji dowodzenia istotne byłoby zidentyfikowanie oraz monitorowania stanu psychofizjologicznego żołnierzy; b) wydajnością i zmęczeniem (poprzez stworzenie mechatronicznego egzoszkieletu czyli zautomatyzowanego kombinezonu zapewniającego, ścisłą koordynację i integrację pomiędzy człowiekiem a maszyną), c) inwalidztwem (poprzez zastosowanie bionicznych protez kończyn), d) zdolnościami kognitywnymi (poprzez stymulacje mózgu) oraz nadludzkimi możliwościami (przy użyciu interfejsu mózg - maszyna mająca na celu wykorzystanie mózgu w celu sterowania i kontrolowania urządzeń) (Kamieński 2014, 219).

Trzeci rodzaj ulepszeń związany jest $\mathrm{z}$ inżynierią genetyczną, profilowaniem genetycznym i wzmocnieniami genetycznymi dokonywanymi na różnym etapie życia (Kamieński 2014, 382). Mogą one polegać na ulepszeniu pewnych właściwości fizycznych człowieka, jak np. wzrostu, zwiększenia masy mięśniowej lub choćby wydłużenia życia oraz na zwiększeniu potencjału intelektualnego poprzez podwyższenie poziomu inteligencji, w tym możliwości zapamiętywania, jak również na ulepszeniu czynnika behawioralnego wpływającego na temperament, a w szczególności na stopień agresji, skłonność do depresji, wierność czy lojalność (Leźnicki \& Lewandowska 2013, 118-119; por. Sauter \& Gerlinger 2012; Cynk 2008; Cooke 1983, 298).

Wykorzystanie każdej $\mathrm{z}$ tych metod będzie uzależnione od celu zamierzonego ulepszenia i rodzaju zadań, które wzmocniony człowiek ma wykonać. Realność ich zastosowania rodzi pytanie o granice ich dopuszczalności oraz moralną i prawną odpowiedzialność za skutki zachowań podjętych $\mathrm{z}$ ich wykorzystaniem. Zagadnienia te będą przedmiotem analizy w kolejnych częściach. 


\section{Wybrane podmioty ulepszania - żołnierz i sportowiec}

W niniejszej analizie przedmiotem badań uczyniono dwie profesje: żołnierza i sportowca. Wybór ten podyktowany został przekonaniem, że zawody te mają szczególne znaczenie w funkcjonowaniu państwa, społeczeństwa i jednostki. Ponadto, to $\mathrm{w}$ kontekście właśnie tych zawodów toczy się najbardziej ożywiona dyskusja na temat ulepszania. Podejmowane są próby wytyczenia akceptowalnych i dopuszczalnych granic ulepszeń. Zasadne jest bowiem pytanie, czy biorąc pod uwagę wspomniany aspekt celów działania osób wykonujących te zawody, ocena dopuszczalności ulepszania człowieka jako takiego, poprawianie jego umiejętności ze względu na wykonywane przez niego szczególnie istotne zadania, może się zmienić. Żołnierz i sportowiec wydali nam się przypadkami szczególnie interesującymi. Generalnie bowiem, wyznaczanie granic polepszania człowieka dokonuje się przy uwzględnieniu następujących kryteriów: przyjętych zasad moralności, norm kulturowych i obyczajowych, norm prawnych, różnego rodzaju umów czy konwencji, oczekiwań społecznych i, co podkreśla się najczęściej, skutków związanych z polepszaniem natury człowieka. Nie bez znaczenia jest doniosłość dóbr, których ochronie lub zdobyciu ma służyć działalność podmiotu ulepszonego, a tym samym cel ulepszenia. Pojawia się pytanie to, czy ze względu na te dobra tolerancja dopuszczalności może się zwiększyć, a w niektórych przypadkach nawet pojawi się obowiązek podjęcia działań mających za cel ulepszenie? Kwestią dla naszych rozważań fundamentalną jest także ustalenie, czy przyjmowane rozumienie ulepszania, a także wątpliwości związane z naturą człowieka, powinny być rozumiane i analizowane niezależnie od tego, jakiego podmiotu one dotyczą. Kryterium pełnienia określonej funkcji społecznej może mieć wpływ na ocenę ulepszenia. Można oczywiście pytać o zasadność tak ustalonego kryterium. Nie jest to bowiem kwestia pojęciowa, lecz odnosi się ona bezpośrednio do problematyki uzasadnienia. Czy argumenty przedstawiane $\mathrm{w}$ dyskusjach nad transhumanizmem pozostają tak samo ważne? Metody używane przez naukowców, co do zasady, nie zmieniają się. Używane farmaceutyki są bardzo podobne, a w niektórych przypadkach identyczne. Celem ogólnym, niezależnie od tego, kto jest ulepszany, jest poprawienie wydolności zarówno umysłowej jak i fizycznej człowieka, jednak zmienia się cel, jakiemu to ulepszenie ma służyć. Czy zatem możemy używać tych samych argumentów za, jak i przeciw dopuszczalności ulepszania, gdy dyskutujemy nad poprawą kondycji żołnierza, sportowca, czy tak zwanego zwykłego człowieka? Czy tak samo należy oceniać dążenie do większej sprawności osoby, której zadaniem jest obrona ojczyny, ratowanie ludzi, jak sportowca startującego na olimpiadzie czy matki, która chce mieć wyjątkowo uzdolnione dziecko?

Te czynniki sprawiają, że kwestia ulepszania ma nie tylko wymiar etyczny czy moralny, lecz - co szczególnie ważne - również wymiar prawny. 
Ze względu na owe dobra kwestia ta nie może być ignorowana przez państwo i precyzyjne reguły dotyczące metod ulepszaniu winny zostać ustanowione.

Poniżej przedstawione zostaną sposoby ulepszania stosowane $\mathrm{w}$ wojsku i sporcie. Następnie przejdziemy do rozważenia argumentów, które podnoszone są w dyskusjach nad ulepszaniem natury człowieka w kontekście tych zawodów. Nasza uwaga skupiona będzie przede wszystkim na tych sposobach ulepszania, które budzą najwięcej kontrowersji, a zatem na wewnętrznym i sztucznym ulepszaniu zdrowej jednostki, przy wykorzystaniu osiągnięć współczesnej farmakologii, technologii i genetyki.

\section{1 Żołnierz}

Przedstawione powyżej rozróżnienia dotyczyły środków, za pomocą których można ulepszyć/poprawić zdolności zarówno fizyczne, jak i kognitywne człowieka. Jak zostało to już zaznaczone, dotyczy to sytuacji, gdy punktem wyjścia jest zdrowy człowiek, a zadaniem „ulepszacza” jest wzmocnienie już posiadanych zdolności bądź ich rozwinięcie.

Zacznijmy od kwestii związanych z ulepszaniem żołnierza, który zarówno z punktu widzenia państwa, społeczeństwa, jak i jednostki, pełni szczególnie ważną rolę. Funkcjonalnie pojęcie żołnierza oznacza osobę pełniąca służbę $w$ siłach zbrojnych danego kraju, stojącą na straży niepodległości i granic państwa (Sejm RP 1992). Jest on członkiem sił zbrojnych, chroni bezpieczeństwo i pokój, ale bierze również udział w zwalczaniu klęsk żywiołowych, likwidacji ich skutków, działaniach antyterrorystycznych i z zakresu ochrony mienia, akcjach poszukiwawczych oraz wielu innych działaniach mających charakter całkowicie pokojowy (Sejm RP 2015)7. Wypełnianie tych zadań - zarówno w trakcie wojny jak i pokoju wymaga od niego wyjątkowej sprawności fizycznej i intelektualnej. Jaki zatem powinien być żołnierz idealny? Żołnierza, który wypełniałby wszystkie swoje bojowe i pokojowe zadania cechować powinna przede wszystkim najwyższa skuteczność - zarówno na polu walki. jak i w warunkach pokojowych. Jednostka, której umiejętność samodzielnego myślenia może być wspomagana odpowiednimi urządzeniami, charakteryzuje się niezwykłą odpornością na ból, potrafi się „naprawić”, nie wymaga dużej ilości snu czy odpoczynku, nie wymaga klasycznego pokarmu, posiada olbrzymią siłę. Z jednej strony

\footnotetext{
7 Warto w tym miejscu przytoczyć art. 2a Ustawy zgodnie z którą: „Siły Zbrojne, realizując zadania konstytucyjne, w zakresie ochrony niepodległości państwa, niepodzielności jego terytorium oraz zapewnienia bezpieczeństwa i nienaruszalności jego granic, mają prawo stosowania środków przymusu bezpośredniego, użycia broni i innego uzbrojenia, z uwzględnieniem konieczności i celu wykonania tych zadań, w sposób adekwatny do zagrożenia oraz $\mathrm{w}$ granicach zasad określonych $\mathrm{w}$ wiążących Rzeczpospolitą Polską ratyfikowanych umowach międzynarodowych oraz międzynarodowym prawie zwyczajowym". Przepis ten bowiem wyraźnie wskazuje w jakiego rodzaju niebezpiecznych zadaniach biorą udział żołnierze, a jednocześnie jaki jest cel ich działań.
} 
doskonała maszyna do zabijania - gdyby zaszła taka potrzeba, z drugiej niezastąpiony ratownik. To te właściwości są najbardziej pożądane z punktu widzenia skuteczności działań armii i państwa mającego za zadanie chronić swoich obywateli. Gdyby składała się ona $\mathrm{z}$ takich jednostek byłaby niepokonana. Czy te cechy to jedynie fantazja, którą można zobaczyć jedynie w filmach science fiction? Jak pokazują wyniki współczesnych badań, niektóre z wymienionych pomysłów już stały się rzeczywistością, inne będą zrealizowane w niedalekiej przyszłości. Obecnie prowadzi się bowiem badania na ogromną skalę i przy zaangażowaniu wielomilionowych funduszy by zbudować takiego idealnego wojownika. Jednak budzą one szereg kontrowersji.

Naturalnym sposobami ulepszania żołnierza są oczywiście ciągłe ćwiczenia fizyczne i mentalne. Żołnierze wyposażani są różnego rodzaju sprzęt mający ułatwić im wykonywanie zadań. I choć czasem doniesienia o katorżniczych ćwiczeniach i niezwykłych urządzeniach, mogą budzić wątpliwości, w ogólnym rozrachunku większość przyjmuje je za dość oczywiste czy wręcz konieczne. Żołnierz musi być bardziej wytrzymały i sprawny niż tak zwany zwykły obywatel. Ciążą przecież na nim wyjątkowo odpowiedzialne zadania. Czy oznacza to, że można jego sprawność polepszać sięgając po sztuczne i wewnętrzne środki? Zaczynając od steroidów (Hughes, Shelton, \& Hughes 2010), poprzez wymienioną kategorię go pills (Tennison \& Moreno 2012), na którą składa się dość bogaty katalog środków służących zwiększeniu sprawności kognitywnej, poprzez ingerencję w mózg żołnierza, uodpornienie go na ból czy brak snu lub jedzenia. Czy w usprawnianiu żołnierzy poprzez wyposażenie ich $\mathrm{w}$ wysoko nowoczesny sprzęt jak zewnętrzny szkielet, kask bezpośrednio podłączony $\mathrm{z}$ dowództwem i jednocześnie monitorujący stan żołnierza (Lin, Mehlman, \& Abney 2013, 24) jest jego ulepszeniem, czy może jedynie dodatkowym oprzyrządowaniem mającym zwiększyć skuteczność na polu walki?

Przyjrzyjmy się zatem, jakiego rodzaju „ulepszeniom” są poddawane osoby służące $\mathrm{w}$ armii. Charakterystyka tychże metod i ich efektów ma bowiem bezpośredni wpływ na ich ocenę. Badanie nad ulepszaniem żołnierzy są prowadzone są od wielu lat, a postęp $\mathrm{w}$ tej dziedzinie jest $\mathrm{z}$ roku na rok coraz większy. Nie ulega naszym zdaniem wątpliwości, że problem ten powinien być rozważany nie tylko na gruncie moralnym, ale co szczególnie ważne - także na płaszczyźnie prawnej. Tworzący prawo nie może bowiem zignorować faktu, że oto na naszych oczach dokonywane są doświadczenia na ludziach, a ich wyniki są weryfikowane często w trakcie działań wojennych czy misji wojskowych. Wyniki tych badań wykorzystywane są zarówno do zabijania ludzi, jak i ich ratowania.

Instytucja, która specjalizuje się i słynie z finansowania tego rodzaju projektów, to amerykańska Agencja Zaawansowanych Projektów Badawczych w Obszarze Obronności - DARPA. W ramach tej organizacji realizowanych jest 
szereg przedsięwzięć, które bezpośrednio lub pośrednio mają na celu podniesienie sprawności osób służących w siłach zbrojnych. Można by powiedzieć, że stworzenie właśnie idealnego żołnierza jest jednym $\mathrm{z}$ podstawowych zadań Agencji. Jak głosiło hasło rekrutacyjne DARPA: „Be all that you can be, and a lot more".

Stworzenie idealnego żołnierza spełniającego warunki, o których pisaliśmy wyżej, jako inteligentnej maszyny służącej neutralizacji wroga, a jednocześnie nie powodującej strat własnych stanowi główny cel badań Agencji, realizowanych $\mathrm{w}$ ramach różnego typu projektów. Jednym z nich jest projekt „szczepionki bólu” (Annas \& Annas 2009, 286). Odkryta w jego ramach substancja przeznaczona jest do blokowania silnego bólu w czasie krótszym niż 10 sekund, a jej działanie trwa 30 dni. Testy pokazały, że szczepionki te nie tłumią innych reakcji - kognitywnych i emocjonalnych. Dotknięcie dłonią gorącego przedmiotu nadal powoduje automatyczną reakcję jej cofnięcia. Ale ból po oparzeniu staje się znacznie mniejszy. Podobnie jak z raną postrzałową, która wywołuje zapalenie i obrzęk. Zastosowanie szczepionki powoduje, że żołnierz nie odczuwa tak silnego bólu, jak „nieulepszony” człowiek.

Do takich badań należy także program w ramach którego naukowcy starają się zmodyfikować metabolizm żołnierzy (Garreau 2006), tak aby umożliwić im sprawne funkcjonować bez snu i bez żywności nawet do tygodnia. Prowadzone są także badania nad możliwością przetrwania bez tlenu (Kurzweil 2011, Shachtman 2007). Inny program ma na celu zbadanie możliwości zatrzymania krwawienia poprzez skoncentrowanie myśli na ranie (Bielitzki 2002). Cognitive Technology Threat Warning System (CT2WS) to natomiast program mający na celu opracowanie pomocy wizualnej wspomaganej komputerowo, która natychmiast identyfikuje zagrożenia, które żołnierz może tylko podświadomie widzieć. Program Regenesis, inspirowany badaniami nad zwierzętami, które natura wyposażyła w naturalną zdolność odbudowy utraconych kończyn (głównie żaby), zwany obecnie Restorative Injury Repair (Beard 2008, 155) ma na celu ustalenie biologicznych uwarunkowań odrastania oderwanych części ciała, tak by możliwe było to również dla ludzi, co w przypadku rannych żołnierzy ma szczególne znaczenie (Anonymous 2012). The Future Combat System to z kolei jeden z programów związanych $\mathrm{z}$ kontrolowaniem żołnierza $\mathrm{w}$ warunkach stresu. Ponadto projektowane są kaski i kamizelki, służące do monitorowania mózgów żołnierzy i przetwarzania danych, aby pomóc im poruszać się po polu bitwy i komunikować się pod ostrzałem (Burnam-Fink 2011). Protetyka, sztuczne kończyny robota, które łączy się w układzie nerwowym tak, by działały jak normalne narządy, to jedne $\mathrm{z}$ wielu projektów będących $\mathrm{w}$ trakcie badań klinicznych w szpitalu Johna Hopkinsa.

Kolejne projekty związane z ulepszaniem żołnierzy związane są także $\mathrm{z}$ rozwojem farmakologii. Najlepszym przykładem jest wspominany już modafinil, który pierwotnie dopuszczony został do obrotu jako lek dla 
narkoleptyków, czyli osób, które często i w niekontrolowany sposób zasypiały. Ten powszechnie dostępny lek na receptę, o nazwie handlowej Provigil, był także testowany na młodych, zdrowych pilotach śmigłowców armii amerykańskiej. Jak wykazały doświadczenie, jego zażycie pozwoliło na bezpieczna pracę, podczas której byli skupieni, czujni i zdolni do radzenia sobie ze złożonymi problemami przy wielogodzinnych misjach. Następnie, po dobrze przespanych ośmiu godzinach, okazywało się, że mogą zrobić to ponownie przez kolejne 40 godzin (Kelley, Webb, et al. 2010).

Omówione przykłady wyraźnie wskazują kierunki badań prowadzonych i wspieranych przez państwo. Wojny są rozgrywane przez człowieka i choć żołnierze są wyszkoleni, wyposażeni i obsługiwani lepiej niż kiedykolwiek wcześniej w historii, nie zmienia się jednak faktu, że nadal stanowią najsłabsze ogniwo armii. Jednak ten stan rzeczy może wkrótce się zmienić. Ulepszanie przekracza kolejne granice wyznaczone przez naturę i rozwój technologii, a odpowiedź na pytanie o dopuszczalność i granice ulepszania natury człowieka staje się jednym $\mathrm{z}$ istotnych problemów etycznych i prawnych. Nie ulega wątpliwości, że prawodawca musi zmierzyć się zarówno $\mathrm{z}$ problemem metod, za pomocą których ulepszenie jest uzyskiwane, jak i skutków takich zabiegów. Ustalić granice dopuszczalnego ulepszania. Szczególnie ważne staje się to pytanie w odniesieniu do żołnierzy, zwłaszcza w kontekście struktury wojskowej, możliwości legalnego i nielegalnego wywierania wpływu na podwładnych. Czy w imię ochrony bezpieczeństwa państwa ulepszanie powinno być w pełni dopuszczalne, a w niektórych przypadkach nawet obowiązkowe? Czy istnieje zgoda na zbudowanie idealny żołnierza - maszyny do zabijania, a jednocześnie człowieka niosącego ratunek? Kolejna kwestia, która wymaga rozważenia dotyczy zarzutów o uznanie tak ulepszonego żołnierza za broń biologiczną. Jak podnoszą niektórzy naukowcy, taki ulepszony żołnierz, może być zatem zgodnie z Konwencją dotycząca broni biologicznej uznany jako „czynnik biologiczny”. A zatem zgodnie z 1 art. rozumiany jako broń biologiczna, której używanie w warunkach wojennych jest zabronione (Lin, Mehlman, \& Abney 2013).

Przedstawione wcześniej projekty wskazują różnorodne cele, w jakich mają być wykorzystane środki i techniki ulepszania żołnierzy, stanowiące ingerencję $\mathrm{w}$ naturę człowieka. Ma ona oczywiście różny zakres, skalę $\mathrm{i}$ metodę. Należy jednak pamiętać o tym, że ceną za ulepszanie kondycji żołnierza może być jego życie i zdrowie.

Wymienione już go pills i no-go pills pozwalają na pozostawanie przez długi czas w dobrej formie mentalnej, co dla żołnierza jest szczególnie ważne, bowiem niejednokrotnie misje przez niego wykonywane trwają wiele godzin i związane są ze szczególnie niebezpiecznymi i odpowiedzialnymi zadaniami. Dotyczy to zarówno działań wojennych, jak i w różnego typu akcji ratunkowych $\mathrm{w}$ trakcie pokoju. Wielogodzinne sterowanie samolotem czy 
innym pojazdem, przeprowadzanie działań wojennych na terytorium wroga, zmusza często żołnierzy do ponadludzkiego wysiłku. Pełnie skupienie przez 10 czy 15 godzin, dla normalnego człowieka, nawet gdy nie wykonuje odpowiedzialnego zadania jest trudne, a przecież mowa jest tu o warunkach wojennych czy niezwykle stresujących akacjach ratowniczych, podczas których każda decyzja jest na wagę ludzkiego życia. Farmaceutyki określane zbiorczo jako go pills umożliwiają utrzymanie koncentracji przez wiele godzin. Dexedrine czy Aderal, należące do tej grupy środków farmokologicznych, wielokrotnie były nie tylko zalecane żołnierzom, lecz wręcz nakazane bywało ich zażycie w trakcie odbywania misji wojskowych (Directorate Generale for Internal Policies 2007, 27). Obecnie wszystkie sektory usług wojskowych używają dekstroamfetaminę do podtrzymania efektywnych działań misji lotniczych w bojowych warunkach przedłużającej się operacji, gdzie efekt zmęczenia przychodzi dość szybko i jest szczególnie niebezpieczny (Greenwood \& Oria 2008). Ma to zredukować ewentualne błędy związane ze zmęczeniem. Większość z leków które są wykorzystywane w armii w tym celu, zostały dopuszczone przez amerykańską Agencję Żywności i Leków, jako skuteczne lekarstwo na narkolepsję lub inne choroby o podłożu neurologicznym. A zatem, gdy mówimy o skutkach ubocznych ich zastosowania, to pojawia się pytanie, czy gdyby rzeczywiście ich zażywanie było tak niebezpieczne, to czy organizacja odpowiedzialna za wprowadzenie leków na rynek dopuściłaby je do obrotu? Problem z zastosowaniem tego typu leków obecnie nie dotyczy ich skutków ubocznych, które może dopiero zostaną wykryte za wiele lat, bowiem obecnie podkreśla się, że pozostawanie przez wiele godzin pod ich wpływem nie przynosi poważnych dolegliwości. To co „jedynie” się pojawia, to kwestia uzależnienia, gdy są przyjmowane zbyt długo. Jednak i tu DARPA prowadzi badania nad udoskonalonym wersjami pigułek, a mianowicie - Ampakine (CX717), która jest jeszcze w fazie testów, ale rezultaty jej stosowania są bardzo obiecujące. Wstępne badania wykazały, że CX717 posiada ogromny potencjał zapobiegania zmęczeniu i utrzymania wysokiej wydajności (Wesenten, Reichardt, \& Balkin 2007). To co powinno skupić naszą uwagę, to fakt, że ze względu na szczególnie pożądane efekty zastosowania go pills, ich zażycie może być przedmiotem przymusu stosowanego zarówno ze strony dowódców, jak i towarzyszy broni. Wielu żołnierzy skarży się na niedopuszczalne działania ze strony dowódców, którzy zmuszają swoich podwładnych do zażywania tego typu leków (Jones, Watson 2013). Pozostawanie przez żołnierza przez kilkanaście godzin w stanie ciągłej gotowości, bez uszczerbku dla jego działań, stanowi pożądany efekt działania medykamentu. Zwiększa skuteczność jego działań, zmniejszając jednocześnie ryzyko błędów. Jednak presja jego użycia, czy to legalna czy nie, budzi zdecydowany sprzeciw moralny. Żołnierz powinien być skuteczny, to nie ulega wątpliwości, lecz czy państwo ma prawo żądać od niego poświęcenia własnego zdrowia, zmuszać do zażywania tego typu farmaceutyków, 
ingerencji $\mathrm{w}$ funkcjonowanie jego organizmu po to, by misja została wykonana?

Kolejnym przykładem działań związanych z ulepszaniem żołnierza jest podawanie leków w celu zwalczania stresu pourazowego (PTSD). Traumatyczne doświadczenia na polu walki pozostawiają nie tylko fizyczne, lecz także psychiczne ślady. Często też osoba doświadczająca takiego stresu jest nie tylko niezdolna do walki, lecz nie radzi sobie po powrocie do normalnego, cywilnego życia. Takie skutki służby w wojsku, są podobnie jak wiele innych, bardzo niepożądane. Dodatkowo badania wykazują, że wśród osób cierpiących na stres pourazowy niezwykle wysoki jest odsetek żołnierzy podejmujących próby samobójcze (Kuehn 2009). Nie tylko zmniejsza to skuteczność armii, lecz także wpływa na rekrutację ochotników. Neuronauka także i tu przychodzi z pomocą. Już ponad 13 lat temu naukowcy przedstawili wstępne dowody, że propranolol, podany po traumatycznym przeżyciu, może złagodzić późniejsze objawy stresu pourazowego. Leki przeciwdepresyjne, które często stosowano, wykazywały również dość wysoką skuteczność, zaś w przypadku leków uspokajających była ona nieco mniejsza (Bleich, Siegel, Garb, \& Lerer 1986). Współczesna nauka udowodniła, że najlepszą metodą pozbycia się takich objawów PTSD, jak napady paniki, koszmary, obsesje, pojawiające się problemy $\mathrm{z}$ alkoholem, narkotykami, przemoc rodzinna, depresja czy wspomniana tendencja samobójcza, będzie możliwość blokowania wspomnień. Antydepresanty oraz leki uspakajające nie wywołują takiego efektu, a dodatkowo powodują szereg skutków ubocznych. Jedną ze skutecznych metod jest zażycie beta-blokerów. Hamują one przechowywanie traumatycznych wspomnień. Beta-blokery znane są głównie jako leki zażywane przez osoby cierpiące na choroby układu krążenia, zmniejszają bowiem objawy lęku, takie jak kołatanie serca i drżenie, nawet gdy są stosowane w niskich dawkach (Sauter \& Gerlinger 2013, 84). Jednocześnie stosowanie tych leków jest zakazane w niektórych dyscyplinach sportu, bo choć, jak twierdzą naukowcy, nie wywołują dużych efektów ubocznych, to zmniejszają ciśnienie krwi, przez co w niedozwolony sposób wpływają na wyniki osiągane przez sportowca i jako takie znalazły się na liście zakazanych substancji dopingujących. Co ciekawe, są one często zażywane także przez artystów, pragnących pozbyć się termy, opanować nerwy (Lieb 2010, 85). Jednak w tym przypadku nie mówi się o ulepszaniu, a o uwolnieniu się od niepożądanych efektów tremy. Ich występ dzięki beta-blokerom nie jest lepszy, a jedynie redukuje symptomy niepokoju (Kenny 2011, 221). Muzycy mogą dzięki nim grać tak dobrze, jak pozwala na to ich przygotowanie i ćwiczenia. Przyjmuje się, że jeśli stres osłabia występy powinien być traktowany jak lekarstwo, a nie „polepszacz” (Lederman 1999). Nawiasem mówiąc, beta-blokery to nie jedyne środki medyczne redukujące objawy PTSD. Kolejne to środki należące do grupy inhibitorów wychwytu serotoniny (serotonin-reuptake inhibitors) (Annas \& Annas 2009). 
Skuteczny lek, który pozwoliłby żołnierzom zapomnieć o wydarzeniach na polu walki, to marzenie każdego dowódcy, lekarza i polityka. Czy jednak nie pojawia się pytanie o konsekwencje zapominania traumatycznych przeżyć. Pozostawiamy na boku rozważania dotyczące możliwości zastosowania tego typu leków przy innych niż wojenne, pourazowych przeżyciach jak gwałt, przemoc, których ofiarą może być każdy. Za możliwością korzystania $\mathrm{z}$ takiej zdobyczy nauki niewątpliwie przemawia dobro żołnierza. Nikt przecież nie chciałaby by wojenny bohater cierpiał każdego dnia, tylko dlatego, że mózg człowieka nie potrafi zapomnieć. W tym jednak przypadku należy mówić raczej o leczeniu, niż ulepszaniu. Celem bowiem podania beta-blokerów lub innych leków o podobnym działaniu jest przywrócenie, a nie polepszenie ponad standard równowagi psychicznej żołnierza. Jednak nie wolno pomijać „ciemnej strony” zapominania. Trudne doświadczenia, jakkolwiek będące bardzo dolegliwe, a czasem nawet dramatyczne $\mathrm{w}$ skutkach, posiadają również wymiar edukacyjny. Ich doświadczenie i znajomość to nie tylko nauka dla jednostki ich doświadczającej, tak by w przyszłości mogła unikać błędów, albo uczyć innych, lecz także nauka dla przyszłych pokoleń. Pamięć o przeszłości to jedna z najważniejszych wartości ludzkości. Możliwość wymazania z pamięci żołnierzy czy ofiar wojny budzi pewne obawy. Mogłaby ona rodzić pokusę jej nadużycia. Jak wyglądałyby wojny, gdyby jak w filmach fantastycznych, można było usunąć wszystkie jej doświadczenia z ludzkiej pamięci? Jak wyglądałaby historia świata, gdybyśmy wymazali $\mathrm{z}$ pamięci wydarzenia $\mathrm{z}$ Auschwitz, tortury więźniów okresu stalinizmu, masakr w Afryce? Jak wyglądałby procesy zbrodniarzy nazistowskich po II Wojnie Światowej gdyby ci, którzy ocaleli, nic nie pamiętali? Z jednej strony zdajemy sobie sprawę jak traumatyczne wydarzenia wpływają na jednostkę, ale jak uczy historia, o pewnych wydarzeniach nie wolno ludzkości zapomnieć. Te dwa rozbieżne punkty widzenia ukazują jeden z wielu dylematów związanych z ulepszaniem człowieka. W tym przypadku konieczność pamięci przyszłych pokoleń o dramatycznych wydarzeniach, prawdy historycznej stoi w opozycji do zdrowia, a nawet życia jednostki i bezpieczeństwa państwa.

\subsection{Sportowiec}

Wzmacnianie i ulepszanie natury ludzkiej w związku z dynamicznym rozwojem medycyny jest obecnie stosowane w bardzo wielu dziedzinach życia. Jedną z nich jest sport, przy czym szczególnego znaczenia problematyka dopingu nabiera w sporcie zawodowym. Obecnie jest to sfera objęta daleko idącą reglamentacją i standaryzacją, począwszy od samej definicji dopingu poprzez zarządzanie badaniami antydopingowymi, systemami służącymi do zbierania informacji o miejscu i czasie pobytu zawodników, aż do 
antydopingowych postępowań dyscyplinarnych i wymierzanych w ich ramach sankcji. Są to zarówno regulacje prawa krajowego, jak i międzynarodowego, o różnym charakterze, tak prawa twardego, jak i miękkiego. Swym zakresem obejmują działania (techniczne i operacyjne) w zakresie zapobiegania, wykrywania i ścigania działań mających na celu sztuczne wspomaganie i ulepszanie organizmu sportowców.

Pojęcie dopingu zwykle kojarzy się z podejmowaniem różnych działań, najczęściej nielegalnych, których celem jest poprawianie wyników sportowych, istotnych z punktu widzenia uprawianej dyscypliny sportu szybkości, siły, wydolności czy koncentracji ludzkiej. Nie jest jednak tak, że pojęcie to przynależy wyłącznie do dziedziny sportu. Jego sens sprowadza się do określonego, ukierunkowanego działania ulepszającego czy wzmacniającego, które może być praktykowane w każdej dziedzinie życia. Dopingiem w najogólniejszym znaczeniu, będzie więc każde stosowanie środków, których celem jest poprawianie możliwości ludzkich i to niezależnie od tego, czy dotyczy to sportu, pracy czy życia codziennego ${ }^{8}$. W związku z tym za doping może być uznane każde wykorzystanie przez żołnierza, lekarza czy sportowca metod, zmierzających do zwiększenia naturalnego potencjału fizycznego lub psychicznego. W tym fragmencie tekstu poddane analizie zostaną jednak problemy tradycyjnie wiązane $\mathrm{z}$ dopingiem sportowym, używanym w sporcie zawodowym.

To ogólne rozumienie dopingu należy doprecyzować poprzez wskazanie kilku definicji legalnych, które występują w aktach prawa międzynarodowego oraz w prawie polskim (Piechota 2010).

Zgodnie z Konwencją antydopingową sporządzoną w Strasburgu dnia 16 listopada 1989 r. (Sejm RP 1989) doping w sporcie oznacza podawanie sportowcom (osobom regularnie biorącym udział $w$ zorganizowanych formach aktywności sportowych) lub używanie przez nich farmakologicznych klas środków dopingujących oraz stosowanie metod dopingowych.

Z kolei Międzynarodowa Konwencja o zwalczaniu dopingu w sporcie UNESCO z dnia 19 października 2005 (Sejm RP 2007) stanowi w art. 2 pkt. 3, że naruszenie przepisów antydopingowych w sporcie oznacza jedno lub więcej z poniższych zdarzeń: a) obecność substancji zabronionej lub jej metabolitów albo markerów w próbce fizjologicznej sportowca; b) użycie lub próba użycia substancji zabronionej lub metody zabronionej; c) niewyrażenie zgody lub bez ważnego uzasadnienia niezgłoszenie się na pobranie próbki po powiadomieniu zgodnie z obowiązującymi przepisami antydopingowymi lub w inny sposób unikanie pobrania próbki; d) naruszenie odpowiednich

8 Samo zjawisko dopingu jak i termin nie są nowe. Środki wspomagające były używane już w starożytności przy okazji zawodów sportowych jak i ceremonii religijnych. Po raz pierwszy słowo „doping” pojawiło się $\mathrm{w}$ jednym $\mathrm{z}$ angielskich słowników w roku 1889. Natomiast po raz pierwszy przypadek użycia środka wzmacniającego udokumentowano w $1865 \mathrm{r}$. 
wymogów określających dostępność sportowca do kontroli poza zawodami, w tym nieprzedstawienie wymaganych informacji na temat miejsca pobytu oraz niepoddanie się badaniom ogłoszonym w oparciu o rozsądne zasady; e) manipulowanie lub próba manipulowania jakąkolwiek częścią kontroli antydopingowej; f) posiadanie substancji lub metod zabronionych; g) handel dowolną substancją zabronioną lub metodą zabronioną; h) podanie lub próba podania sportowcowi substancji zabronionej lub metody zabronionej lub pomaganie, zachęcanie, ułatwianie, podżeganie, ukrywanie lub każdy inny rodzaj współdziałania większości się $\mathrm{z}$ naruszeniem przepisów antydopingowych lub próbę ich naruszenia.

Z kolei definicja dopingu aktualnie stosowana przez Światową Agencję Antydopingową to „wystąpienie jednego lub więcej naruszeń przepisów antydopingowych określonych $\quad \mathrm{w}$ Artykułach 2.1 do 2.8 Kodeksu Antydopingowego z 2009 roku"9. Doping w tym przypadku jest po prostu zdefiniowany odsyłająco jako naruszenie przepisów aktu prawnego. Dopingiem jest zatem wszystko, co Agencja uznała za doping.

W prawie polskim istotne dla problematyki definicje zawiera ustawa $\mathrm{z}$ 25 czerwca 2010 r. o sporcie (Sejm RP 2010). Sport zdefiniowany jest jako wszelkie formy aktywności fizycznej, które przez uczestnictwo doraźne lub zorganizowane wpływają na wypracowanie lub poprawienie kondycji fizycznej i psychicznej, rozwój stosunków społecznych lub osiągnięcie wyników sportowych na wszelkich poziomach. Ustawa wymienia sytuacje kwalifikowane jako doping. W ustępie 3 art. 43 ustawa precyzuje, że substancją zabronioną jest substancja mogąca służyć poprawie wyniku sportowego, której użycie pozostaje w sprzeczności z uczciwością rywalizacji sportowej, określona w załączniku nr 1 do Międzynarodowej konwencji o zwalczaniu dopingu w sporcie, sporządzonej w Paryżu dnia 19 października 2005 r. (Sejm RP 2007) oraz jego zmianach dokonanych w trybie art. 34 tej konwencji. Natomiast metodą zabronioną jest działanie mogące służyć poprawie wyniku sportowego, pozostające $\mathrm{w}$ sprzeczności $\mathrm{z}$ uczciwością rywalizacji sportowej, określone $w$ tymże załączniku, oraz jego zmianach dokonanych $\mathrm{w}$ trybie art. 34 tej konwencji (ust. 4). Ponadto substancją lub metodą zabronioną jest także substancja lub działanie utrudniające wykrycie substancji lub metody określonej w ust. 3 i 4, określone w załączniku nr 1 oraz jego zmianach dokonanych w trybie art. 34 tej konwencji (ust. 5). Ustawa przewiduje, że organem właściwym do zwalczania dopingu w sporcie jest Komisja do Zwalczania Dopingu w Sporcie. Ponadto podmioty prowadzące działalność sportową, w szczególności polskie związki sportowe, realizują odpowiedzialność dyscyplinarną za stosowanie dopingu w sporcie w zakresie określonym w ich regulaminach (Wach 2004).

9 Światowy Kodeks Antydopingowy, który został przyjęty po raz pierwszy w roku 2003, wszedł w życie w roku 2004. 
Doping może być i jest praktykowany na wiele sposobów. Spośród stosowanych metod najczęściej wymienia się: doping farmakologiczny, polegający na podawaniu biologicznie czynnych związków chemicznych (np. sterydów anabolicznych działających głównie poprzez zwiększanie masy mięśniowej, takich jak testosteron i tetrahydrogestrinon, specyfików okresowo zwiększających wydolność lub zapobiegających odczuwaniu bólu przy nadmiernym wysiłku fizycznym, tzw. stymulantów takich jak amfetamina, ecstasy, modafinil, i ich pochodne.) (Ministerstwo Sportu 2007); doping fizjologiczny - polegający na wymianie płynów ustrojowych, zwłaszcza krwi (np. w postaci autotransfuzji lub plazmaferezy), przeszczepach tkanek (mięśni i ścięgien), stosowanie zabiegów zbijających masę ciała poprzez chirurgiczne usuwanie tkanki tłuszczowej oraz doping genetyczny polegający na modyfikacji kodu genetycznego zawodnika (a więc ingerencji w ekspresję genów zawodnika, prowadzącą do wzrostu liczby komórek tkanek szczególnie potrzebnych do uprawiania sportu - głównie mięśni oraz szpiku kostnego, bądź dokonywaniu wszczepu obcych tkanek, wcześniej zmodyfikowanych genetycznie, które namnażają się następnie w organizmie (Chrostowski 2005).

Z kolei ze względu na zamierzony efekt, zwykle wynikający ze specyfiki uprawianej dyscypliny, wskazuje się na doping siłowy - którego celem jest osiągnięcie jak największego siły przy stałej masie ciała, doping wytrzymałościowy - którego celem jest trwałe zwiększenie zdolności organizmu do znoszenia długotrwałego, intensywnego wysiłku fizycznego i doping stymulujący - którego celem jest czasowe zwiększenie odporności na ból i wysiłek poprzez stosowanie technik zapobiegających odczuwanie bólu i zmęczenia.

Każda regulacja ograniczająca wolność jednostki wywołuje pytanie o jej zasadność i granice oraz o mniej lub bardziej paternalistyczną rolę prawa. W sporcie zakaz stosowania dopingu uzasadnia się na kilka sposobów. Jako cel działań antydopingowych przywoływana jest najczęściej ochrona podstawowego prawa sportowców do uczestniczenia w sporcie wolnym od dopingu, a tym samym promowanie zdrowia, uczciwości i równości sportowców na całym świecie. Sprowadza się to do zachowania podstawowej wartości w sporcie czyli jego ducha, który zakłada poszanowanie samego siebie, innych uczestników i reguł gry. Rywalizacja ma prowadzić do osiągnięcia doskonałości w działaniu tak indywidualnym jak i zespołowym, a przez to do wzmocnienia charakteru - zwłaszcza gotowości do poświęceń i zaangażowania, budowania i wzmacniania wspólnoty, a w jej ramach solidarności (Komisja do Zwalczania Dopingu w Sporcie 2014).

Ustanowienie antydopingowych przepisów materialnoprawnych oraz procesowych, jak również powołanie odpowiednich instytucji było konsekwencją traktowania dopingu jako zjawiska niepożądanego w świecie 
sportu, a samo pojęcie dopingu od początku posiadało zdecydowanie negatywną konotację.

U podstaw zakazów antydopingowych leży założenie, że wartość sportu opiera się na naturalnych i uczciwych sposobach osiągania sukcesów poprzez pracę, trening i wykorzystanie talentów, przy czym obowiązek uczciwego działania odnoszony jest nie tylko do samego sportowca, ale także rywali, jak i publiczności. Rywalizacja sportowa ma odbywać się w warunkach równości przy wykorzystaniu naturalnych predyspozycji i zdolności. Pojawią się tu zatem trzy elementy rywalizacji sportowej - uczciwa rywalizacja, ćwiczenia i równość. Stawiając zatem pytanie o możliwość dopuszczenia ulepszania sportowców, podważa się niejako istotę sportu. W przekonaniu wielu osób, jakiekolwiek nienaturalne wspomaganie, abstrahując od ewentualnych skutków ubocznych, będzie naruszeniem tej istoty czy jak nazywają niektórzy - ducha sportu.

Zacznijmy zatem od rozważenia, czym jest naturalne ulepszanie kondycji sportowca i jakie skutki uboczne może to wywołać. 0 naturalnych i sztucznych metodach ulepszania wspominaliśmy już wcześniej. Pomimo że w sporcie takie rozróżnienie budzi wątpliwości, a o szkodliwości konkretnego sposobu ulepszania często trudno wyrokować, to jest ono pomocniczym kryterium przy ustalaniu zakazów. Zakaz stosowania szkodliwych substancji może rodzić także pytanie o to, czy dorosły nieubezwłasnowolniony człowiek nie może, korzystając z przysługującej mu wolności, dobrowolnie podjąć decyzji o prowadzeniu niezdrowego (a niekiedy nawet zagrażającego życiu) trybu życia polegającego na zażywaniu środków dopingujących? ${ }^{10}$ Czy prawo powinno $\mathrm{w}$ tę sferę ingerować? Pytanie jest tym bardziej zasadne, że stosowanie takich specyfików wpływa bezpośrednio tylko na osobę je aplikującą. Z drugiej jednak strony państwo od dawna ingerowało $w$ tę sferę wolności obywatela, ustanawiając różnego rodzaju ograniczenia i zakazy, kierując się szkodliwością określonych substancji. Argumenty używane w dyskusjach dotyczących narkotyków czy alkoholu, głównie związane są przecież ze szkodliwość działania tych substancji. Ich stosowanie ma oczywiście inny cel, niemniej jednak pytanie pozostaje aktualne, a spór między libertariańską wizją państwa, zgodnie z którą obywatel powinien móc robić ze swoim ciałem co tylko zapragnie, a konserwatystami i paternalistami, prawdopodobnie nie zostanie szybko zakończony (Husak \& de Marneffe 2005). W przypadku substancji używanych w sporcie ten argument zostaje nieco osłabiony. Dawno już zaprzestano wykorzystywania strychniny (Hartgens \& Kuipers 2004), czy innych równie niebezpiecznych środków. Obecnie używane są często farmaceutyki, które są dopuszczone przez agencje

10 Wolność sportowca jest dodatkowo ograniczona poprzez międzynarodowy system ADAMS, na podstawie którego sportowcy zobligowani są do informowania o miejscu pobytu każdego dnia, w celu dokonania przez lotne brygady antydopingowe kontroli (zob. Sas-Nowosielski 2002). 
do spraw leków w większości krajów. Zdając sobie sprawę, że skutki uboczne zażywania środków dopingujących dostępnych obecnie na rynku trudno określić, bowiem wiele $\mathrm{z}$ nich to nowoczesne leki, wydaje się, że dopiero $\mathrm{z}$ perspektywy lat będzie można właściwie je ocenić. Toteż nie mamy wątpliwości, że kwestia szkodliwego wpływu na stan zdrowia sportowca, jakkolwiek ważna, nie może być używana jako jeden $\mathrm{z}$ podstawowych argumentów. Użycie takiego argumentu oznaczałoby bowiem, że w sytuacji stworzenia substancji ulepszającej nie wywołującej żadnych szkodliwych efektów, należałoby dopuścić doping jako legalną metodę wspomagania sportowców.

Kolejna kwestia związana jest wymogiem równości. Każdy ma prawo i możliwość podjęcia rywalizacji sportowej, której reguły wyznaczane są przez określone konwencje często $\mathrm{w}$ oparciu o praktykę i tradycję. Zasady gry w zawodowym sporcie są ściśle określone przez regulaminy - wymogi dotyczące warunków fizycznych samych sportowców, sprzętu, jeśli takiego wymaga dana dyscyplina i oczywiście zasady rywalizacji. Reguły dyscypliny mają stworzyć równe szanse każdemu. Czy w związku z tym zażywanie specyfików dopingujących może być objęte regułami gry? Czy zakładana równość powinna obejmować zakaz ich stosowania? A innymi słowy, czy zakaz ich stosowania gwarantuje równość szans tak jak w przypadku standaryzacji i wymogów co do sprzętu, kostiumów pływaków czy skoczków narciarskich itp.? Czy o równości w sporcie można mówić, jeśli wiadomo, że osiąganie najlepszych rezultatów nie jest tylko i wyłącznie zasługą osobistych i naturalnych predyspozycji zawodnika, ale także całego sztabu szkoleniowomedycznego, którego jakość w znacznej mierze zależy od przekazanych na ten cel środków i zaawansowania technologicznego. Należy jednak zwrócić uwagę, że także sprzęt, kostiumy podlegają ścisłej kontroli, a jedynie te, które spełniają wymogi regulaminu, są dopuszczane. Co roku jednak pojawiają się kolejne ulepszone wersje kostiumów czy sprzętu, z którego korzystają sportowcy, i co roku pojawiają się nowe regulacje, zakazujące lub dopuszczające ich używanie. Osiągnięcia techniki pozwala na optymalizację zarówno treningów, jak i osiąganych przez zawodników wyników. Coraz doskonalsze metody są przy tym wykorzystywane - jak chociażby namioty tlenowe (Browne \& LaChance 1999). Podobne skutki wywołują wyjazdy w wysokie góry. Jednak pytania pozostają te same. Jak oceniać ulepszania? Które z nich należy dopuścić jako naturalne i nie zagrażające życiu i zdrowiu sportowca, a których zakazać? Wydaje się, że decyzje w tej sprawie podejmowane są tylko w pewnym zakresie w oparciu o wyniki badań, w dużej zaś bazują na uznaniowej ocenie osób zasiadających w różnego rodzaju federacjach sportowych i to od ich decyzji zależy uznanie jakieś środka za doping lub nie.

Kolejny problem dotyczy tego, czy doping powinien być zakazany wyłącznie co do środków poprawiających wydolność fizyczną, czy także 
psychiczną. 0 ile ta pierwsza bezpośrednio wpływa na wyniki sportowe, o tyle druga „tylko" umożliwia ich wykorzystanie poprzez opanowanie lęku czy stresu, które są czynnikami oddziaływującymi w sposób niekorzystny na osiągany rezultat i wynik zawodów. Podobnie jak u wspomnianych już artystów występujących zawodowo na scenie, tak i wśród sportowców trema i stres są czynnikami pogarszającymi wyniki. Muzycy czy artyści nie są badani przez konkursami na obecność „polepszaczy”. Nie można wykluczyć pianisty z konkursu szopenowskiego dlatego, że przed występem zażył Propranolol. Jego występ niewątpliwie zyskał, ale by zagrać pięknie Nokturn b-moll Chopina, musiał ćwiczyć przez wiele godzin. Beta-bloker pozwolił mu jedynie pozbyć się czynnika, który nie pozwoliłby mu na pełne zaprezentowanie swojego talentu. Beta-blokery należą do substancji dopuszczalnych także w niektórych dyscyplinach sportowych (Brantigan, Brantigan, \& Joseph 1982), niemniej jednak $\mathrm{w}$ innych traktowane są jako doping i w związku $\mathrm{z}$ tym zakazane (World Anti-Doping Agency 2015). Do sportów gdzie obowiązuje ten zakaz należą m.in. łucznictwo, bilard, golf, strzelanie czy sporty podwodne. To pokazuje, że tam gdzie opanowanie, „pewna ręka” jest czynnikiem szczególnie ważnym, leki te są traktowane jako ulepszacze. Tam gdzie znaczenie opanowania stresu jest mniejsze, federacje sportowe dopuszczają ich stosowanie. A zatem kryterium stanowi nie tyle szkodliwość, ile to, czy dana cecha, która ma podlegać ulepszeniu determinuje wynik sportowy. Tam gdzie opanowanie nie jest szczególnie dopuszczono taką możliwość, tam gdzie opanowanie nerwów jest ważne, musi być ono rezultatem ciężkiej pracy sportowca. W golfie jest oszustwem, w piłce nożnej już nie zagraża uczciwej rywalizacji.

Problematyka ulepszania która jest przedmiotem niniejszej analizy dotyczy nie tylko tak zwanych „normalnych” zawodów czy sportowców. Zagadnienie to należy również odnieść do osób z różnego rodzaju wadami fizycznymi czy psychicznymi, którzy tak jak wszyscy inni, mają prawo brać udział w współzawodnictwie sportowym. Czy zakaz wykorzystywania środków dopingujących powinien obowiązywać zarówno podczas zwykłych zawodów czy także podczas różnego paraolimpiad. W drugim przypadku sprawa wydaje się bardziej skomplikowana ze względu na dysfunkcje fizyczne i psychiczne zawodników wymagające różnorakich interwencji medycznych doprowadzających organizm do „normalnego” poziomu funkcjonowania i podjęcia wysiłku fizycznego. Problem ten, dyskutowany jest nie tylko w odniesieniu do paraolimpiad, dotyczy także tzw. terapeutycznego wykorzystywania środków niedozwolonych $\mathrm{w}$ sytuacji stwierdzonej u zawodnika choroby, która wymaga leczniczego stosowania specyfików zakazanych przez przepisy antydopingowe ${ }^{11}$. Najbardziej chyba znanym przykładem problemu związanego z inwalidztwem sportowca i kontrowersji

$11 \mathrm{~W}$ narciarstwie przykładem tego problemu były zarzuty stawiane przez biegaczkę Justynę Kowalczyk wobec Marit Bjoergen. 
dotyczących ulepszania, był udział Oscara Pistoriusa (Camporesi 2008) w olimpiadzie. Sportowiec ten przez wiele lat brał udział $w$ zawodach paraolimpijskich. Jednak postanowił, że mimo swojego kalectwa powinien być dopuszczony do zwykłej olimpiada, co też się stało. Warto przypomnieć, że od kolan w dół, Pistorius miał przymocowane protezy dostosowane do biegów. Dyskutowano nad tym, czy te odpowiednio skonstruowane sztuczne kończyny nie dają mu niezgodnej $\mathrm{z}$ przepisami przewagi. Ostatecznie zadecydowano o jego dopuszczenie. Zawodów nie wygrał, ale to co dla nas istotne to fakt, że posiadanie nawet najlepszego sprzętu, bo przecież protezy w tym przypadku były skonstruowane, tak by podczas biegu uzyskać najlepszy efekt, nie oznacza, wygranej. Sport to nadal ciężka praca, żmudne ćwiczenia i talent. Ulepszacz może oczywiście zwiększyć szanse, ale niczego nie gwarantuje. To nadal sportowiec i jego umiejętności decydują o wygranej. Trudno ocenić jak skończyłaby się sprawa Pistoriousa, gdyby zawody wygrał.

Kolejną kwestią związaną z argumentem z równości jest zagadnienie dostępności danego środka. Rozważmy następujący przykład: jeśli ktoś wygrywa olimpiadę matematyczną, tylko dlatego, że w przeciwieństwie do pozostałych uczestników używał kalkulatora, to nie należy mu się ani podziw dla jego matematycznych umiejętności ani nagroda. Takiego zawodnika wszyscy potraktowaliby właśnie jak oszusta. Gdy jednak zmienimy perspektywę i przyznamy każdemu uczestnikowi prawo do korzystania z kalkulatora, a zatem gdy każdy będzie miał równą szansę i liczyć się tu będzie umiejętność właściwego jego wykorzystania przy rozwiązywaniu równań matematycznych, ocena zawodnika wykorzystującego maszynę zmienia się. Każdy przecież $\mathrm{z}$ uczestniczących miał taką samą możliwość. To rodzaj zawodów, reguły nimi rządzące i fakt, że wszyscy mają te same szanse, startują z tego samego miejsca, decyduje o naszej ocenie danej aktywności pod kątem uczciwości i równości. Czy w sporcie jest podobnie? Tu niestety nie ma jednoznacznej odpowiedzi. Wątpliwości, które się pojawiają omówiliśmy powyżej. Trudno postawić znak równości między użyciem kalkulatora i steroidami. Analogię raczej znajdziemy między używanymi przez skoczka nartami i kalkulatorem, zakładając, że w obu przypadkach sprzęty mają te same parametry. Druga kwestia - szkodliwość. Trzecia, szczególnie ważna, dotyczy oceny ulepszania pod kątem celu danej aktywności. Przeprowadzanie obliczeń matematycznych $\mathrm{w}$ głowie i na kalkulatorze to dwie różne aktywności i z dwóch różnych perspektyw mogą być oceniane. Tę perspektywę tworzy cel działania. Jeśli tym celem jest jak najszybsze i pewne ustalenie wyniku - to czy matematyk korzysta z komputera, czy z własnej głowy, jest w zasadzie obojętne. Ma być skuteczny i osiągnąć cel. Gdy natomiast celem jest sprawdzenie naturalnych zdolności matematycznych, często osiąganych dzięki żmudnym ćwiczeniom, to w jaki sposób osoba przeprowadza te działania, jak dochodzi do wyniku, jest przedmiotem oceny i oczywiście może być przedmiotem podziwu. Podobnie jest ze sportem. 
Oczywiście zawodnikom zależy na tym by osiągnąć jak najlepszy wynik, ale wynik sam w sobie nie jest celem. On „jedynie” wskazuje jakie postępy uczynił zawodnik i jak jego wynik plasuje się w stosunku do innych. W tym przypadku przedmiotem oceny i podziwu jest ciężka praca, wysiłek włożony w zdobycie medalu, talent i umiejętności. Wiedząc, że sprinter osiągnął wynik poniżej $8 \mathrm{~s}$ na $100 \mathrm{~m}$ dzięki zażyciu tabletek czy dzięki specjalnemu sprzętowi, nie podziwialibyśmy jego samego, a naukowców którym udało się taki farmaceutyk wyprodukować lub skonstruować taki sprzęt.

W wielu krajach szereg substancji i technik stosowanych $\mathrm{w}$ dopingu nie jest jednak zabroniona i dlatego korzystanie $\mathrm{z}$ nich nie jest nielegalne $\mathrm{w}$ świetle prawa danego państwa. Osoby uprawiające sport $\mathrm{w}$ celach rekreacyjnych lub uprawiające sport zawodowo w dyscyplinach, w których nie obowiązuje zakaz dopingu, mogą z niego korzystać, a kwestia uszczerbku na własnym zdrowiu jest $w$ tej sytuacji ich prywatną sprawą. Natomiast sam doping jako taki jest karalny tylko w nielicznych krajach. Przykładem są tutaj Włochy. Reakcja prawna może jednak dotykać innych jego aspektów, chociażby $\mathrm{w}$ postaci zakazu wytwarzania, posiadania i dystrybucji czy przewożenia niedozwolonych związków chemicznych czy farmaceutyków oraz w postaci zakazów wykonywania określonych zabiegów medycznych. Mogą to być więc przepisy prawa karnego, ale i administracyjnego (np. celnego ${ }^{12}$ ) czy cywilnego. W konsekwencji odpowiedzialność może ponosić zawodnik, trener, lekarz jak również osoba nie związana bezpośrednio ze środowiskiem sportowym.

\section{Aspekty dopuszczalności enhancement}

Przedstawiona analiza dotyczyła dwóch zawodów, które zostały uznane za szczególnie interesujące z punktu widzenia problematyki ulepszania. Pomimo stosowania bardzo podobnych metod ulepszania i ich skutków, polegających na poprawie szeroko rozumianych umiejętności człowieka, oceny dopuszczalności ulepszania człowieka $\mathrm{w}$ tych zawodach różnią się znacząco. Te różnice wynikają nie tyle $\mathrm{z}$ celu ulepszania, jakim jest zwiększenie zdolności kognitywnych i fizycznych człowieka, ale zależą od rodzaju aktywności, do których te zawody należą i celów, jakim służą działania podejmowane w ramach tych aktywności. W naszym przekonaniu, odpowiedź

\footnotetext{
12 „Gdy w 1998 roku żandarmeria francuska dokonała nalotu na kolarski peleton Tour de France, do postawienia przed sądem kolarzy, lekarzy, trenerów i szefa grupy Festina wykorzystano między innymi prawo celne, zabraniające wwożenia pewnych substancji na terytorium Francji. Podobnie postąpiły organa państwowe, ścigające dopingowy proceder w środowisku kolarskim w Belgii. W 2000 roku francuski szosowiec Richard Virenque stanął przed sądem w Lille oskarżony o dopingowy spisek. Instrumenty śledztwa policyjnego i prokuratorskiego posłużyły rozpracowaniu dopingowej mafii towarzyszącej szosowcom włoskim, kompromitując między innymi arcymistrza Marco Pantaniego" (Petruczenko 2010).
} 
na pytanie o dopuszczalność wzmacniania człowieka zależy właśnie od celów, jakim ma ono służyć i dóbr, których osiągnięcie ma ułatwić. Kiedy wyeliminowane zostaną skutki uboczne działania ulepszaczy, co jest jedynie kwestią czasu i postępu w nauce, argument ze szkodliwości ich działania i związany z nim argument polityczny (Czy państwo ma prawo zakazywać pełnoletniemu obywatelowi zażywania szkodliwych substancji?) stracą racje bytu. Jedynie analiza etyczna, związana z problematyką działań człowieka, pozostanie aktualna. Cel aktywności ludzkiej, dobra uzyskiwane dzięki danej aktywności oraz przypisana jej istota powinny być zatem podstawowymi przedmiotami dyskusji nad dopuszczalnością ulepszania.

Analizy Alasdaira MacIntyre'a dotyczące praktyk moralnych, zawarte przede wszystkim w jednym z najważniejszych jego dzieł After Virtue (1996), stanowić będą podstawę dalszych rozważań. Nie będziemy przedstawiać szczegółowo zaproponowanej przez niego koncepcji cnót, a skupimy się głównie na jednym $\mathrm{z}$ trzech (obok osobowości narracyjnej i tradycji) podstawowych pojęć jego filozofii (Horton \& Mendus 1994) - to jest na pojęciu praktyki. MacIntyre definiuje praktykę jako „wszelką spójną i złożoną formę społecznie ustanowionej, kooperatywnej działalności ludzkiej, poprzez którą dobra wewnętrzne wobec tej działalności są realizowane w procesie dążenia do realizacji wzorców doskonałości, które są charakterystyczne dla tej formy działalności i które po części ją definiują: dzięki tak pojętej działalności praktycznej ludzka zdolność do osiągania doskonałości oraz ludzkie pojęcie celów i dóbr ulegają systematycznemu poszerzeniu" (MacIntyre 1996, 187). To właśnie poprzez praktyki wyraża się ludzka tożsamość. Praktykami są na przykład gra w szachy, medycyna, architektura, badania w fizyce czy biologii, a w ich ramach realizowane są cnoty, które oferują różnorodność dóbr, zarówno wewnętrznych, jak i zewnętrznych względem tych praktyk. Dobra wewnętrzne obejmują formy rozumienia lub zdolności fizyczne, które mogą być nabywane jedynie przez dążenie do doskonałości/cnoty w ramach jakiejś praktyki. Dobra zewnętrzne w stosunku do praktyk obejmują bogactwo, sławę, prestiż i władzę. Istnieje wiele sposobów, aby uzyskać dobra zewnętrzne. Można to zrobić uczciwie lub w drodze oszustwa.

MacIntyre ilustruje konflikt między dobrami zewnętrznymi i wewnętrznymi za pomocą przypowieści o dziecięcej grze w szachy. Inteligentne dziecko otrzymuje propozycję nauki gry w szachy, choć nie ma na to żadnej ochoty. Jednakże drugi gracz proponuje mu za wygraną słodycze. Dopóki celem, dla którego dziecko gra w szachy jest wygrana słodyczy, ma ono wszelkie powody, aby oszukiwać, bowiem w ten sposób może wygrać więcej cukierków. Gracz ma jednak nadzieję, że przyjdzie czas, gdy dziecko odkryje inne dobra związane $\mathrm{z}$ grą $\mathrm{w}$ szachy - jak umiejętność myślenia analitycznego, strategiczną wyobraźnię, zapamiętywanie czy inne zdolności nierozerwalnie związane z szachami. Są to właśnie dobra wewnętrzne, a jedynym sposobem ich uzyskania są uczciwe ćwiczenia i samodoskonalenie. 
Kiedy to sobie uświadamiamy, to oszukiwanie jest irracjonalne, bowiem gracz oszukuje samego siebie. Żadne oszustwo nie pozwoli mu rozwinąć tych umiejętności. Dobra zewnętrzne (cukierki, czy w przypadku innych praktyk sława, pieniądze, prestiż) można jednak również uzyskać w sposób nieuczciwy, a często są to dobra kuszące dla praktykującego (MacIntyre 1996, 188). Jak twierdzi MacIntyre: „praktyka obejmuje standardy doskonałości i posłuszeństwa zasadom, jak również osiągnięcie dóbr. Włączenie się do praktyki to zaakceptowanie autorytetu tych standardów i nieadekwatność własnej działalności ocenianej $\mathrm{z}$ jej punktu widzenia. To jest poddanie własnych postaw, wyborów, preferencji i upodobań standardom, które aktualnie i częściowo określają praktyki" (idem, 190). Szczególnie ważne jest to, że dobra wewnętrzne są pożądane dla całej społeczności, która uczestniczy w danej praktyce. Ich uzyskiwanie ma dobry wpływ na wszystkich uczestników praktyki. Istotą praktyk leży w osiąganiu dóbr wewnętrznych, szczególnych form doskonałości człowieka, które praktyki czynią możliwymi (Schermer 2008, 360). To właśnie wewnętrzne standardy doskonałości decydują o ocenie praktyki. Najlepszy wynik sportowy nie jest identyczny z wygraną meczu, czy wspinaczka górska nie jest tym samym, co bycie na szczycie góry. Nie oznacza to jednak, że użycie pewnych środków dla polepszenia wyniku będą kolidować $\mathrm{z}$ istotą ludzkiego działania - jak skorzystanie z samolotu by dostać się szybciej do określonego miejsca. Lot samolotem nie jest jednak praktyką w rozumieniu MacIntyre'a.

Analizy szkockiego filozofa można odnieść zarówno do sportu, jak i żołnierstwa. Należy przy tym odróżnić działalność człowieka nakierowaną na praktykę od tej, która jest związana z osiągnięciem określonego celu (Santoni de Sio, Robichaud, \& Vincent 2014). Nie ulega wątpliwości, że sport należy do praktyk w rozumieniu tego filozofa. W przypadku żołnierza jego aktywność niewątpliwie nakierowana jest na cel. Trudno tu wskazać jakieś dobra wewnętrzne definiujące istotę działań wojennych. Żołnierz ma być skuteczny. Walczy w obronie kraju, bierze udział w akcjach ratowniczych, a istota jego działań sprowadza się do efektywności. A zatem podobnie jak dziecko z przypowieści, początkowo zainteresowane tylko zdobyciem słodyczy - ma wszelkie powody, by oszukiwać. W ten sposób w aktywnościach nastawionych na rozwijanie cnót, takich jak sport czy sztuka, ulepszanie człowieka nie powinno być dopuszczalne z moralnego punktu widzenia. Narusza bowiem istotę tej aktywności. Natomiast tam, gdzie najważniejszy jest zewnętrzny cel, powinno się je dopuścić.

Ponadto, przy ustalaniu podstaw zakazu, bądź dopuszczalności w działaniach zorientowanych na praktykę należy podkreślić, że niektóre z ich reguł, jak ma to miejsce $\mathrm{w}$ przypadku sportu, są konstytutywne dla określonego działania. Są niezbędne dla istnienia tej działalności. Obecność tych konstytutywnych reguł stanowi pojęciowe, a priori ograniczenie sposobu, w jaki określona działalność może być wykonywana. Naruszenie lub 
zmiana jednej z tych reguł może spowodować, że dana aktywność straci swoją istotę, naturę. Przykładem jest wcześniej już analizowany przypadek rywalizacji sportowej. Jeśli ktoś pojawia się na starcie maratonu, stojąc na deskorolce, narusza nie tylko reguły sportowe obowiązujące w maratonie, ale także konstytutywną zasadę tej dyscypliny. Zauważmy, że taki „maratończyk” narusza zasady sportu na dwa różne sposoby. Na poziomie etycznym deskorolka daje mu bowiem nieuczciwą przewagę wobec innych biegaczy. Natomiast na płaszczyźnie pojęciowej zniesiona zostanie istota maratonu, a zatem, biorąc pod uwagę, że praktyczne działania człowieka są zdefiniowane przez ich istotę, będą one po prostu należały do innego rodzaju działalności, w tym przypadku - do innej, nienazwanej dyscypliny. W tym drugim kontekście skater robiłby zatem coś „złego” nie tylko w znaczeniu moralnym, ale i metafizycznie, bowiem naruszyłby reguły, które są konstytutywne dla danej działalności (Santoni de Sio, Robichaud, \& Vincent 2014, 183-184).

Powyższe rozważania skłaniają do stwierdzenia, że trudnym jest wyznaczenie jednoznacznych, uniwersalnych i niezmiennych granic dopuszczalności ulepszania natury ludzkiej, obowiązujących w każdej sytuacji i przesądzających o akceptowalności działań ulepszających. Raczej należałoby powiedzieć, że ich wyznaczenie będzie miało charakter kontekstualny, wynikający $\mathrm{z}$ wyjściowego stanu organizmu (ulepszanie/leczenie) oraz charakteru danej aktywności. Poznanie mechanizmów odpowiedzialnych za zachowanie, emocje, zdolności kognitywne i sprawność fizyczną człowieka oraz możliwość ich kontroli otworzyły drogę do poprawiania jego naturalnych cech i zdolności, a w konsekwencji do zatarcia w wielu przypadkach granic między leczeniem a poprawianiem, wzmacnianiem czy ulepszaniem (Kamieński 2014, 59).

Ponadto pojęcie enhancement wiązane jest $\mathrm{z}$ wartościami, a te osadzone są w kontekście kulturowym i historycznym, nie mającym znaczenia transkulturowego. Są to pojęcia kulturowo doniosłe i jako takie, historycznie związane, stanowią rezultat ukształtowanych wartości, tak jak pojęcia choroby, zdrowia czy normalności (Wolpe 2002, 387-395). Dlatego też enhancement jest wyzwaniem nie tylko etycznym, lecz także kulturowym. To właśnie w tym wymiarze często są wyznaczane jego granice. Słusznie podnosi się, że w wyznaczaniu granic są także obecne kryteria, które nie są wyprowadzane $\mathrm{z}$ rozważań nad ulepszaniem człowieka, ale wynikają chociażby $\mathrm{z}$ konieczności zagwarantowania prawa jednostki do samostanowienia (Vogelsang, Hoppe 2011, 39).

Równocześnie poszerzyło się spektrum możliwości stosowania środków ulepszających, obejmując swym zasięgiem różnego rodzaje sytuacje, od zwykłych i codziennych, aż po szczególne i ekstremalne. W tej rzeczywistości pytanie, gdzie leży granica między leczeniem a ulepszaniem, między akceptacją a brakiem akceptacji pewnych poczynań, stało się szczególnie istotne, ale i kłopotliwe (Asch 2006). Zagadnienie jest tym 
bardziej problematyczne, że istnieje znaczne opóźnienie między rozwojem technologii wzmacniających, a niezbędną dyskusją dotyczącą jej właściwego wykorzystania (Lin, Mehlman, \& Abney 2013). Odpowiedź na nie wymaga wskazania punktów odniesienia oraz kryteriów dokonywanych ocen tak moralnych, jak i prawnych.

W każdym razie podkreślić należy, że problemy te nie mają tylko i wyłącznie teoretycznego i akademickiego znaczenia, lecz także istotny wymiar praktyczny, zarówno w sferze moralności, jak i prawa, ponieważ właściwe zakwalifikowanie działań ulepszających decyduje o ich dopuszczalności bądź niedopuszczalności (Lin, Mehlman, \& Abney 2013, 37). Przesądzenie tej kwestii, pierwotnie w sferze moralności, a następnie przez prawo pozytywne (będące odzwierciedleniu przyjętej aksjologii) nastąpić może dopiero po uprzednim rozstrzygnięciu kilku podstawowych kwestii, takich jak zagadnienia wartości i jakości życia oraz znaczenia i skutków naszych działań dla nas samych oraz innych ludzi (Ferdynus 2013,11). Dokonywane w sferze fizycznej lub emocjonalnej działania (czy, jak niektórzy twierdzą, manipulacje) są zawsze związane z wartościowaniem życia i jego jakości, ale dokonuje się to w każdym przypadku ulepszania z osobna. Najogólniejszą zasadniczą granicą, jaką można wyznaczyć, jest zakaz dokonywania działań wbrew naturze ludzkiej, naruszających integralność, tożsamość i osobowość człowieka Chyrowicz 2002, 31) ${ }^{13}$. Treść tym zasadom będzie jednak nadawana w każdym ocenianym przypadku z osobna.

$\mathrm{W}$ pracy przeanalizowałyśmy problematykę enhancement $\mathrm{W}$ kontekście dwóch profesji: żołnierza i sportowca. Wybór ten wynikał z intuicyjnego przekonania, że pełniona przez wykonujących te zawody funkcja społeczna może mieć znaczenie dla wytyczenia granic akceptowalnych i dopuszczalnych ulepszeń, innymi słowy, że zasadnym jest oddzielne mówienie o ulepszaniu człowieka jako takiego, oraz o ulepszaniu człowieka, wykonującego pewne zadania czy wypełniającego pewną rolę społeczną. Żołnierz i sportowiec wydali nam się przypadkami interesującymi, a może nawet wzorcowymi dla prowadzenia takich rozważań.

Generalne wyznaczania granic dozwolonych działań ulepszających naturę ludzką dokonuje się przy uwzględnieniu wielu kryteriów: przyjętych zasad moralności, norm kulturowych i obyczajowych, norm prawnych, różnego rodzaju umów czy konwencji (w tym zasad fair play) oraz oczekiwań społecznych. Nie bez znaczenia jest także status zawodowy wzmacnianego oraz status podmiotu, $\mathrm{w}$ imieniu którego działania ulepszające są podejmowane (np. państwo), jak również doniosłość dóbr, których ochronie ma służyć działalność podmiotu ulepszonego, z założeniem, że im dobra te są bardziej cenione i chronione, tym większa będzie tolerancja dla dokonywania

13 Autorka stawia pytanie dlaczego w ogóle wysuwa się oskarżenie przeciwko doskonałości, skoro dążenie do doskonałości jest jednym z wymogów często powtarzanych $\mathrm{w}$ wielu systemach etycznych? 
ulepszeń. Koniecznym jest także uwzględnienie skutków, jakie działania wywołują bądź mogą wywołać, tak w życiu jednostki, jak i społeczności. Natomiast w płaszczyźnie moralnej, naszym zdaniem za najważniejsze uznać należy uwzględnienie dystynkcji dóbr wewnętrznych i zewnętrznych, powiązanej $\mathrm{z}$ ujęciem praktyki jako działalności konstytuującej ludzką tożsamość.

\section{Literatura}

Ach, J. 2006. Arnd Pollmann. Berlin: Münster.

Anonymous, 2012. "Universal Soldier: Pentagon Eyes Limb-Regenerating Super-Troopers?". Dostęp (URL): http://rt.com/news/pentagondarpa-genes-soldiers-527/.

Annas, C. \& Annas, G. 2009. "Enhancing the Fighting Force: Medical Research on American Soldiers." Journal of Contemporary Health Law and Policy XXV: $1-20$.

Bayertz, K. 2011. "Die menschliche Natur und ihr Wert". Preprints of the Centre for Advanced Study in Bioethics 16, Münster.

Bielitzki, J. 2002. Enhancing Human Performance in Combat. Dostęp (URL): http://archive.darpa.mil/DARPATech2002/presentations/dso_pdf/sp eeches/BIELITZ.pdf

Bleich, A., Siegel, B., Garb, R., \& Lerer, B. 1986. "Post-Traumatic Stress Disorder Following Combat Exposure: Clinical Features and Psychopharmacological Treatment." The British Journal of Psychiatry 149: 365-369.

BMA. 2014. Boosting Your Brainpower: Ethical Aspects of Cognitive Enhancements. A discussion paper from the the British Medical Association. Dostęp: http://enhancingresponsibility.com/wpcontent/uploads/2014/01/Boosting_brainpower_tcm41-147266.pdf

Bostrom, N., \& Roache R., 2008. „Ethical Issues in Human Enhancement.” In J. Ryberg, T. Petersen, \& C. Wolf (eds.), New Waves in Applied Ethics. Michigan: Palgrave Macmillan: 120-152.

Bostrom, N., \& Sandberg, A. 2009. "The Wisdom of Nature: An Evolutionary Heuristic for Human Enhancement." In N. Bostrom \& A. Sandberg (eds.), Enhancing Humans. Oxford: Oxford University Press: 375-416.

Brantigan, C., Brantigan, T. \& Joseph, N. 1982. „Effect of Beta Blockade and Beta Stimulation on Stage Fright." American Journal of Medicine 72: 8894.

Browne, A., LaChance, V., \& Pipe, A. 1999. "The Ethics of Blood Testing As an Element of Doping Control in Sport." Medicine and Science in Sports and Exercise 31: 497-50. 
Burnam-Fink, M. 2011. The Rise and Decline of Military Human Enhancement. Dostęp (URL): http://scienceprogress.org/2011/01/the-rise-anddecline-of-military-human-enhancement/

Camporesi, S. 2008. "Oscar Pistorius, Enhancement and Post-Humans." Journal of Medical Ethics 34(9): 639.

Chrostowski, K. 2005. "Doping genowy-nowe zagrożenie dla sportu". Sport Wyczynowy 9-10 (489-490): 91-99.

Chyrowicz, B. 2002. Etyczne aspekty ingerowania w ludzka psychikę. Lublin: TN KUL 2002

2002. "O ingerencji w ludzką psychikę i kontrowersyjnych korzyściach utraty autonomii". W B. Chyrowicz (red. naukowa), Etyka i technika. Etyczne aspekty ingerowania w ludzkq psychikę. Lublin: TN KUL: 87105.

———, 2004. "O ingerencji w ludzką psychikę i kontrowersyjnych korzyściach naruszenia ludzkiej autonomii”. W J. Brzeziński \& M. ToeplitzWiniewska (red. naukowa), Praktyka psychologiczna $w$ świetle standardów etycznych. Warszawa: Wydawnictwo Szkoły Wyższej Psychologii Społecznej Academica: 81-92.

Cynk, K. 2008. Moralny spór o genetyczne ulepszanie człowieka. Dostęp: http://repozytorium.ur.edu.pl/handle/item/492

Cooke, R. 1983. Wyzwanie naturze: nowy wspaniały świat inżynierii genetycznej. Warszawa: Państwowy Instytut Wydawniczy.

Directorate Generale for Internal Policies. 2007. Human Enhancement Study. Policy Department A: Economic and Scientific Policy. Science and Technology Options Assessment.

Ferdynus, M. 2013. "Czy biomedyczne doskonalenie ludzkiej natury jest „zabawą w Boga?” Studia Warmińskie 50: 9-23.

Fuchs, M. Lanzerath, D., Hillebrand, I., Runkel, T., Balcerak, M., \& Schmitz, B. 2002. Enhancement. Die ethische Diskussion über biomedizinische Verbesserungen des Menschen. Sachstandsbericht 1, Bonn: Verlag.

Garreau, J. 2006. Radical Evolution: The Promise and Peril of Enhancing Our Minds, our Bodies - and What it Means to be a Human. New York: Broadway Books.

Greenwood, M. R. C. \& Oria, M. 2008. Use of Dietary Supplements By Military Personnel. Atlanta: National Academies Press.

Hall, S. 2003. „The Quest for a Smart Pill.” Scientific American 289 (September): 54-65.

Hartgens, F. \& Kuipers, H. 2004. "Effects of Androgenic-Anabolic Steroids In Athletes." Sports Medicine 34: 513-554.

Hołub, G. SDB. 2008. Czy bioetyka potrzebuje pojęcia natury ludzkiej? Próby odrzucenia pojęcia natury ludzkiej. Dostęp: http://www.mp.pl/etyka/podstawy_etyki_lekarskiej/show.html?id=3 6260 . 
Horton, J. \& Mendus, S. (eds.) 1994. After MacIntyre. Critical Perspectives on the Work of Alasdair MacIntyre. Notre Dame: University of Notre Dame Press.

Hughes, J., Shelton, M. C., \& Hughes, T. 2010. "Suspected Dietary Supplement Injuries In Special Operations Soldiers." Special Operations Medical Journal 10 (Summer): 14-24.

Husak, D. \& de Marneffe, P. 2005. The Legalization of Drugs: For \& Against. Cambridge: Cambridge University Press.

Jones, A. \& Watson, P. 2013. Forced Mass Drugging of Us Troops and Underreported Scandal. Dostęp (URL): http://www.infowars.com/ mass-drugging-of-us-troops-an-underreported-scandal/

Judycki, S. 2008. Filozofia sportu. Lublin: Katolicki Uniwersytet Lubelski. Dostęp (URL): http://www.kul.pl/files/57/wydzial/judycki/ filozofia_sportu.pdf

Kamieński, Ł. 2014. Nowy wspaniały żołnierz. Rewolucja biotechnologiczna i wojna $w$ XXI wieku. Kraków: Wydawnictwo Uniwersytetu Jagiellońskiego.

Kelley, A., Webb, C., Athy J., Ley S., \& Gaydos, S. 2010. USAARL Report No. 201106, Cognition-Enhancing Drugs and Their Appropriateness for Aviation and Ground Troops: A Meta-Analysis, United States Army Aeromedical Research Laboratory Warfighter Performance and Health Division. Fort Rucker: United States Army Aeromedical Research Lab.

Kenny, D. 2011. The Psychology of Music Performance Anxiety. Oxford: Oxford University Press.

Komisja do Zwalczania Dopingu w Sporcie. 2014. Polskie Przepisy Antydopingowe. Dostęp (URL): http://www.antydoping.pl/pl/prawo/ modelowe_reguly_antydopingowe.

Krupp, L., Christodoulou C., Melville, P., Scherl, W., MacAllister, W., \& Elkins, L. 2011. "Donepezil Improved Memory in Multiple Sclerosis in a Randomized Clinical Trial." Neurology 26 (April): 1579-1585.

Kuehn B. 2009. "Soldier Suicide Rates Continue to Rise." Medical News and Perspective 18 (March): 1111-1113.

Kula, M. 2012. Doping farmakologiczny w sporcie - kwas ursolowy. Bezpieczny steryd? Dostęp (URL): http://biotechnologia.pl/farmacja/artykuly/ doping-farmakologiczny-w-sporcie-kwas-ursolowy-bezpiecznysteryd,778.

Kurzweil, R. 2011. "Kurzweil Responds: Don't Underestimate the Singularity." MIT Technology Review. Retrieved from (URL): http://www.technologyreview.com /view/425818/kurzweilresponds-dont-underestimate-the-singularity/

Lederman, R. 1999. "Medical Treatment of Performance Anxiety: A Statement in Favor." Medical Problems of Performing Artists 14: 101-102. 
Leźnicki, M. \& Lewandowska, A. 2013, „Biomedykalizacja a genetyczne udoskonalenie człowieka w kontekście analiz bioetycznych". Acta Universitatis Lodziensis. Folia Sociologica 45: 105-121.

Lieb, K. 2010. Hirndoping. Warum wir nicht alles schlucken sollten. Mannheim: Artemis und Winkler.

Lin, P., Mehlman, M., \& Abney, K. 2013. Enhanced Warfighters: Risk, Ethics, and Policy. New York: The Greenwall Foundation.

MacIntyre, A. 1996. After Virtue. A Study in Moral Theory. Paris.

Mahadevan, S., Park, Y. 2008. "Multifaceted Therapeutic Benefits of Ginkgo biloba, Chemistry, Efficacy, Safety, and Uses." Journal of Food Science 73 (January): 14-19.

Ministerstwo Sportu, 2007. Strategia rozwoju sportu w Polsce do roku 2015. Ministerstwo Sportu. Dostęp (URL): www.msport.gov.pl/sport.

Parens, E. 1998. Enhancing Human Traits: Ethical and Social Implications. Georgetown: Georgetown University Press.

Petruczenko, M. 2010. „Czy doping może być przestępstwem?”. Przegląd Sportowy online. Dostęp (URL): http://www.przegladsportowy.pl/inne-dyscypliny,czy-doping-mozebyc-przestepstwem, artykul,89995,1,307.html.

Piechota, R. 2010. "Reguły antydopingowe w prawie międzynarodowym". Studia Iuridica Toruniensia, t. VI: 152-181.

President's Council on Bioethics. 2003. Beyond Therapy: Biotechnology and the Pursuit of Happiness. Washington, DC: President's Council on Bioethics.

Santoni de Sio, F., Robichaud, P., \& Vincent, N. 2014. "Who Should Enhance? Conceptual and Normative Conceptual and Normative Dimensions of Cognitive Enhancement." Humana.Mente Journal of Philosophical Studies 26: 179-197.

Sas-Nowosielski, K. 2002. "Czy zło usankcjonowane przestanie być złem? Refleksje na temat legalizacji doping". Sport Wyczynowy 5-6: 32-40.

Sauter, A. \& Gerlinger, K., 2012. Der pharmakologisch verbesserte Mensch Leistungssteigernde Mittel als gesellschaftliche Herausforderung. Berlin: Edition Sigma.

Sauter, A. \& Gerlinger, K., 2013. The Pharmacologically Improved Human Performance-Enhancing Substances As a Social Challenge. Report for the Committee on Education. Research and Technology Assessment of the German Bundestag. Berlin: Office of Technology Assessement at the German Bundestag.

Savulescu, J. 2011. Enhancing Human Capacities. Oxford: Oxford University Press.

Savulescu, J., Sandberg, A., \& Kahane, G. 2011. "Well-Being and Enhancement." W idem (eds.). Enhancing Human Capacities. Oxford: Blackwell Publishing. 
Schermer, M. 2008. "Enhancemnet. Easy Schortcuts and the Richness of Human Activity." Bioethics 22: 355-363.

Shachtman, N. 2007. „Be More Than You Can Be.” Wired 15.03. Dostęp (URL): http://archive.wired.com/wired/archive/15.03/bemore.html.

Sejm RP 1989. „Konwencja Antydopingowa sporządzona w Strasburgu dnia 16 listopada 1989 roku". Dziennik Ustaw Nr 15 (poz. 149).

Sejm RP. 1992. „Ustawa z dnia 3 października 1992 r. o przysiędze wojskowej”. Dziennik Ustaw Nr 77 (poz. 386): 1329.

Sejm RP. 2007. „Międzynarodowa konwencja o zwalczaniu dopingu w sporcie, sporządzona w Paryżu dnia 19 października 2005 roku". Dziennik Ustaw Nr 142 (poz. 999).

Sejm RP. 2010. „Ustawa z dnia 25 czerwca 2010 r. o sporcie”. Dziennik Ustaw Nr 127 (poz. 857).

Sejm RP. 2015. „Ustawa z dnia z dnia 21 listopada 1967 r. o powszechnym obowiązku obrony Rzeczypospolitej Polskiej”. Dziennik Ustaw Nr 0 (poz. 144).

Tennison, M. \& Moreno, J. 2012. "Neuroscience, Ethics, and National Security: The State of the Art." PLoS Biol 10(3): e1001289. doi:10.1371/journal.pbio.1001289.

Themenheft, 2006. „Enhancement“. Zeitschrift für Medizinische Ethik 52(4).

Vogelsang, F. \& Hoppe, Ch. 2011. „Sollen wir den Menschen verbessern? Versprechungen und Perspektiven des Neuroenhancement". V Forum der Neuroethik, Dokumentation der Tagung 01/2011, Januar, Evangelische Akademie in Rheinland: Bonn Verlag.

Wach, A. 2004. "Odpowiedzialność prawna osób trzecich $\mathrm{w}$ sprawach dopingowych". Sport Wyczynowy 9-10: 75-86.

Wesenten, N., Reichardt R., \& Balkin, T. 2007. "Ampakine (CX717) Effects on Performance and Alertness During Simulated Night Shift Work." Aviation Space Environmental Medicine 78: 937-943.

Wolpe, P. 2002, "Treatment, Enhancement and the Ethics of Neurotherapeutics." Brain and Cognition 50: 387-395.

World Anti-Doping Agency. 2015. "P2. Beta-Blockers". List of Prohibited Substances and Methods. Dostęp (URL): http://list.wadaama.org/list/p2-beta-blockers/\#beta-blockers 


\author{
Justyna Holocher (Kraków) \\ Urszula Kosielińska-Grabowska (Kraków)
}

\title{
Dopuszczalność ulepszania natury ludzkiej (enhancement)
}

\section{Admissibility of Human Enhancement}

\begin{abstract}
Abstrakt. Praca przedstawia moralnoprawne aspekty ulepszania natury ludzkiej, w kontekście poszukiwania odpowiedzi na pytanie o to, w jakim zakresie i wobec kogo mogą zostać zastosowane nowoczesne technologie, których zasadniczym celem nie jest powrót człowieka do zdrowia, lecz ulepszenie (enhancement) jego naturalnego potencjału poprzez zwiększenie siły, wytrzymałości, odporności, sprawności fizycznej oraz możliwości regeneracji, a także poprawienie możliwości kognitywnych w postaci usprawnienia myślenia i polepszenia pamięci. Problematyka enhancement związana jest $\mathrm{z}$ nurtem transhumanizmu, postulującym doskonalenie człowieka i zakładającym możliwość objęcia kontrolą coraz większych obszarów ludzkich aktywności, tak fizycznych, jak i intelektualnych. W poszukiwaniu odpowiedzi na pytanie o granicę moralnej akceptacji ulepszeń natury ludzkiej, przeanalizowane zostały przykłady żołnierza i sportowca, które unaoczniają $\mathrm{w}$ najwyższym stopniu główne problemy omawianego zagadnienia. Wybór tych przykładów wynikał z przekonania, że pełniona funkcja społeczna oraz rodzaj aktywności związanych z jej wykonywaniem mają istotne znaczenie dla wytyczenia granic akceptowalnych ulepszeń człowieka. Naszym zdaniem określenia tej granicy winniśmy dokonać w związku z rozróżnieniem typów aktywności, bazującym na przyjętym przez A. MacIntyre'a podziałem ludzkich działań. Dla MacIntyre’a w działaniach, określanych mianem praktyk, człowiek realizuje dobra wewnętrzne, które jednocześnie definiują daną praktykę i mogą zostać osiągnięte wyłącznie w drodze doskonalenia jego umiejętności i zdolności. Dobra zewnętrzne, które także można osiągnąć poprzez działania, takie jak sława, pieniądze czy prestiż, nie należą do istoty praktyk. Dobra te można bowiem uzyskać zarówno na drodze uczciwej pracy i samodoskonalenia, jak i dzięki oszustwom.

Po rozważeniu szeregu problemów natury teoretycznej i praktycznej, argumentujemy na rzecz tezy, że o dopuszczalności sztucznych ulepszeń oraz wytyczeniu jej akceptowalnych granic rozstrzyga ustalenie, czy dane działania zmierzają do osiągnięcia istotnych celów, takich jak życie, zdrowie ludzkie lub bezpieczeństwo państwa, stanowiących dobro moralne lub społeczne (w obszarze tym zastosowanie ulepszeń będzie nawet niekiedy obowiązkiem), czy też działania te polegają wyłącznie na praktykowaniu cnót służących moralnemu doskonaleniu się człowieka, co powinno się dokonywać tylko
\end{abstract}


dzięki wykorzystaniu naturalnego potencjału ludzkiego. Zatem, granica moralnie akceptowalnego ulepszania natury ludzkiej wyznaczana będzie (na etapie stanowienia i stosowania prawa) poprzez ustalenie natury danej aktywności, jej funkcji i istotności społecznej, a więc jej moralnej bądź społecznej doniosłości.

Słowa kluczowe: Natura ludzka, ulepszanie, transhumanizm, A. MacIntyre, doping w sporcie, udoskonalony żołnierz

\begin{abstract}
The paper presents moral and legal aspects of the human's nature enhancement in the context of answering the questions to what extent and to whom the modern technologies may be applied, which purpose is not the recovery (therapy), but the improvement of natural human potential by increasing the strength, endurance, immunity, physical fitness and human's ability to regenerate, as well as by improving the cognitive capacities in the form of the betterment of human thinking and memory. The problems of enhancement are associated with the movement of transhumanism, which postulates the perfecting of a man and assumes the possibility to control more and more the domains of human activities, both physical and intellectual. In finding the answer to the question of the limits of moral acceptance for the enhancement of human nature, we analyze the cases of a soldier and sportsman, which illustrate the most important problems of the issue. The choice of such examples was due to the belief that social function and the types of activity connected with the exercise of these professions are very important for the determination of the acceptable limits of human enhancement. In our opinion the determination of the limit should be made by referring to the types of activity, based on the division of human activities elaborated by A. MacIntyre. According to MacIntyre, in the case of human activities known as practices, a man achieves internal goods, which define the practice and can only be achieved by improving human skills/abilities. While the external goods, like fame, money or prestige, do not belong to the essence of a practice. For these goods can be achieved both through honest work and self-improvement, and by the fraud.
\end{abstract}

After considering a number of theoretical and practical problems, we argue for the thesis that the admissibility of artificial enhancements and the establishment of its acceptable limits are to be resolved by determining whether a given activity is oriented to achieve essential goods, like life, health or national security, which constitute the moral or social good (in such cases the use of enhancements sometimes will be even a duty), or this activity merely consist in the practice of virtues for the moral improvement of man, which should be made exclusively by using the natural human potential. Thus, the limit of the morally acceptable enhancement of the human nature is to be 
determined (at the stages of law-making and law-application) by indicating the nature of a given activity, its social function and importance, and therefore its moral or social significance.

Keywords: Human nature, enhancement, transhumanism, MacIntyre, doping in sport, enhanced soldier.

Ethics in Progress (ISSN 2084-9257). Vol. 6 (2015). No. 1, pp. 85-118.

doi: 10.14746/eip.2015.1.8 